\title{
Millets for Food Security in the Context of Climate Change: A Review
}

\author{
Rachit Saxena ${ }^{(\mathbb{})}$, Sai Kranthi Vanga *(D) Jin Wang ${ }^{(\mathbb{D}}$, Valérie Orsat and Vijaya Raghavan \\ Department of Bioresource Engineering, Faculty of Agricultural \& Environmental Sciences, McGill University, \\ 21111 Lakeshore Rd, Sainte-Anne-de-Bellevue, QC H9X 3V9, Canada; rachit.saxena@mail.mcgill.ca (R.S.); \\ jin.wang6@mail.mcgill.ca (J.W.); valerie.orsat@mcgill.ca (V.O.); vijaya.raghavan@mcgill.ca (V.R.) \\ * Correspondence: sai.vanga@mail.mcgill.ca
}

Received: 8 June 2018; Accepted: 26 June 2018; Published: 28 June 2018

\begin{abstract}
A growing population means an ever-increasing demand for food. This global concern has led to antagonism over resources such as water and soil. Climate change can directly influence the quality and availability of these resources, thereby adversely affecting our food systems and crop productivity, especially of major cereals such as rice, wheat and maize. In this review, we have looked at the availability of resources such as water and soil based on several modeling scenarios in different regions of the world. Most of these models predict that there will be a reduction in production rates of various cereal crops. Furthermore, all the major cereal crops are known to have a higher contribution to global warming than alternative crops such as millets which should be considered in mitigating global food insecurity. In this study, we have used the data to predict which regions of the world are most adversely affected by climate change and how the cultivation of millets and other crops could aid in the reduction of stress on environmental resources.
\end{abstract}

Keywords: food security; soil conditions; water resources; agricultural productivity; millets; climate change

\section{Introduction}

Tackling hunger and feeding the world population are two of the biggest challenges of the modern world. Reasons contributing to this issue range from deficiencies in the supply of micro- and macronutrients, shortage in production of foods leading to supply-demand imbalances, and conflicts destabilizing various parts of the world. Although several of these triggers for hunger can be addressed leading to a slight reduction in the population suffering from hunger and malnutrition from almost one billion in 1990-1992 to 850 million in 2010-2012, the threat of climate change and global warming still lingers [1]. Estimates show that the reduction in food production rates along with the added pressure of feeding a population exceeding 9 billion by 2050 could lead to $2-3$ billion people suffering from hunger, food and nutritional insecurities [2,3].

Climate change and increasing global average temperatures are reported to have a direct impact on crop yields, crop productivity and overall sustainability of our food systems. Although some estimates show that a few regions could benefit from climate change due to increased productivity and yields, this will not be sufficient to feed the higher number of inhabitants globally [4]. Furthermore, most of the scientific community agrees that the current rates of global warming and emissions of greenhouse gas would significantly reduce the overall crop productivity. Thus, reducing the greenhouse gas emissions to control global temperatures plays a crucial role in achieving food security. However, the agricultural sector is one of the primary contributors to greenhouse gases such as methane into the atmosphere. Higher emissions are generally caused by intensive agricultural practices which are being followed in different locations around the world $[5,6]$. 
Over the course of the last few decades, various researchers have used different models to predict the outlook of soil conditions and water resources around the world, 50-100 years from now, which have been summarized and presented. Although there have been previous attempts to review the modeling data, they are generally limited to a specific region or a limited aspect of climate change. However, in this paper, the modeling data are presented in three broad categories: soil conditions, water resources and agricultural productivity. The criteria for selecting a study for this review are mentioned below in a dedicated section. Combining the information from these studies from select regions around the world could provide us with an insight on how to tackle the issue of climate change. Furthermore, millet has been discussed as an alternative cereal due to its inherent ability to grow in adverse conditions which include low-quality soils and lack of irrigation facilities.

\section{Millets Cultivation}

Cereal crops are not only a major source of macronutrients such as carbohydrates, fats and proteins but also have a significant global warming potential. Among all the major cereal crops, wheat has the highest global warming potential of around 4 tons $\mathrm{CO}_{2}$ eq/ha followed by rice and maize (around 3.4 tons $\mathrm{CO}_{2}$ eq/ha). These crops also have a high carbon equivalent emission of 1000, 956 and $935 \mathrm{~kg} \mathrm{C} /$ ha for wheat, rice and maize, respectively [7]. Despite their higher emission rates, they are widely cultivated and are primary sources of nutrition for the global population. However, the carbon footprints of other minor cereal crops such as millets and sorghum are comparatively lower. This is one of the primary reasons millets can be one of the crops that could reduce carbon footprint in the world [8]. According to the FAO (2014), the most cultivated varieties of millet are Pearl, Proso, Foxtail, Japanese Barnyard, Finger and Kodo and are cultivated across the globe (Figure 1). Different types of millets have different scientific names as well as common name based on the region in which they are cultivated, and these millets are cultivated in different regions of the world and require different growing conditions (Table 1). Rice, wheat, maize and to a lesser extent millet are consumed daily as primary sources of nutrition by billions of people around the globe. Temperature and water availability dictate the growth pattern of these crops. Rice and maize are grown in areas with ample supply of water, whereas cultivation of wheat is done largely in areas with limited water resources and appropriate temperatures. Sorghum and millets are grown in areas where water resources are scarce. Furthermore, millets can be cultivated in semi-arid and arid regions because of their tolerance to biotic and abiotic stresses and their substantial yield in low-quality lands with minimal input $[8,9]$.

Millets are generally thermophilic (thriving at relatively higher temperatures) and xerophilic (can reproduce with limited water input). A wide variety of millets are found in different regions of the world that require different soil types for their normal growth (Table 1). Pearl millet can grow on poor sandy soils and is well suited for dry climates due to its ability to use moisture efficiently compared to sorghum or maize. Pearl millets are thus generally grown in areas having marginal soil with low annual rainfall in the range of 200-500 mm [10]. According to the FAO (2014), pearl millet is the sixth most important cereal grown worldwide. Pearl millet is a traditional crop in Central, Eastern and Southern Africa; in Western Africa, particularly in the Sahel; in India and Pakistan; and along the southern coast of the Arabian peninsula [11]. It is considered to be an important crop to ensure food security in regions of Africa and India [12].

Finger millet, also known as Eleusine coracana L., is grown in parts of India and Africa. Taking production statistics into account, it secures the sixth position in India among major cereal grains following wheat, rice, maize, sorghum and bajra [13]. It can thrive at higher temperatures and in soils with higher salinity compared to other cereal crops. Optimum conditions for growing finger millet are temperatures ranging from 11 to $27^{\circ} \mathrm{C}$, soil $\mathrm{pH}$ of 5 to 8.2, and medium rainfall [14]. 


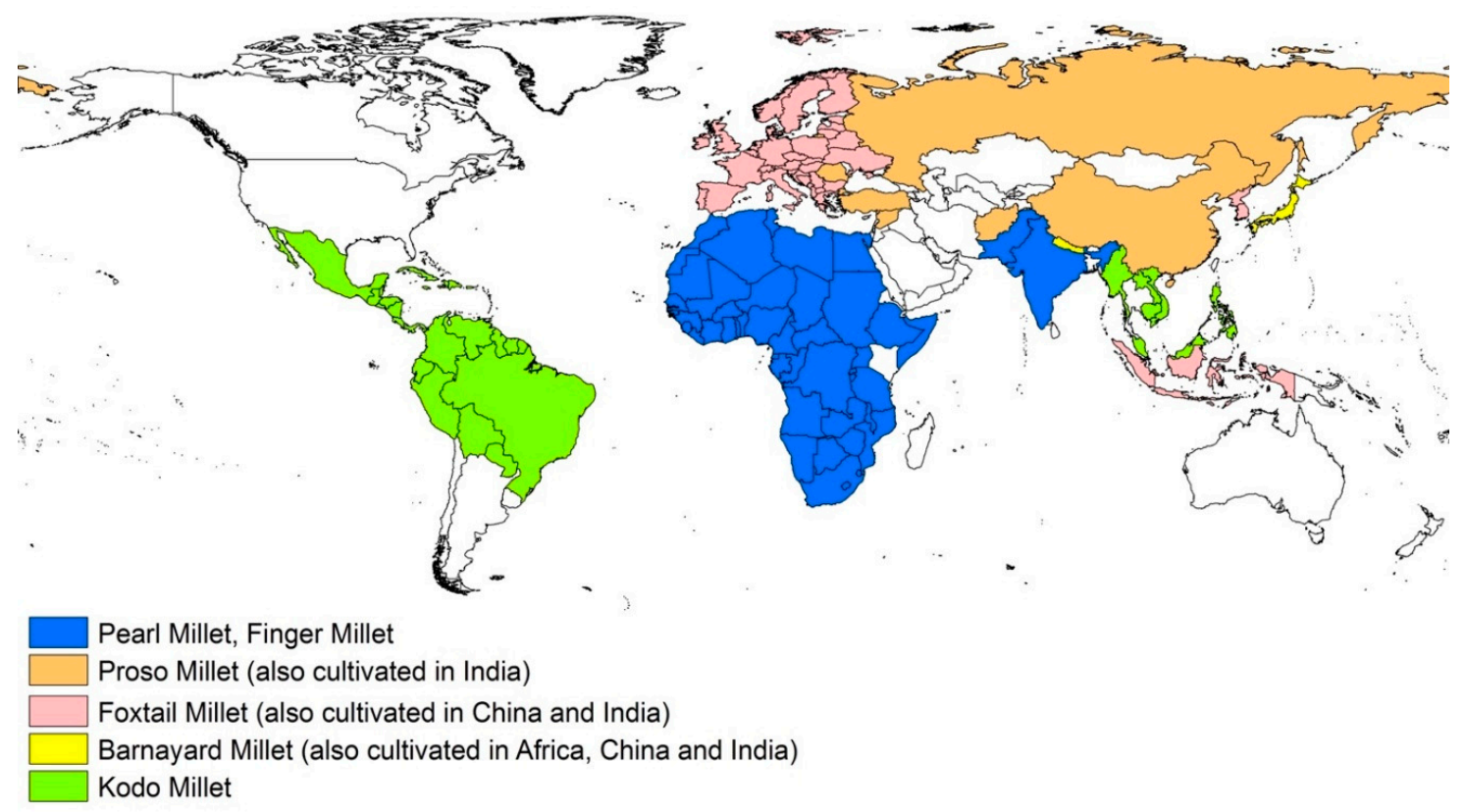

Figure 1. Cultivation of different types of millets around the world.

Proso millet is cultivated in China, India and Russia. It is believed that Proso millet originated in Central and Eastern Asia, and later spread to India, Russia, the Middle East and Europe [15,16]. It is a vital crop in Central and Southern India, Afghanistan, Kazakhstan, Northwest China, Australia, Eastern Europe, Russia, USA and the Middle East including Iran, Iraq, Syria, and Turkey [17]. Proso millet is a short-seasoned crop usually cultivated for 60-75 days, requires an average annual rainfall of less than $600 \mathrm{~mm}$ and an average temperature of $17^{\circ} \mathrm{C}$ during daytime is considered optimum [18].

Seeds of foxtail millets have been found in various sites in Europe, the Middle East, and Eastern and Central Asia dated to the Neolithic and Bronze ages. Today, this millet is widely cultivated in Europe, China, India, Indonesia, the Korean peninsula, and the former U.S.S.R. Foxtail millet has a fast ripening mechanism and a high photosynthetic efficiency; hence, it is perfectly suited to be used as a catch crop [19]. Moreover, it is rich in nutrition and has good resistance to pests and diseases [20]. This crop has a good yield with only single pre-sowing precipitation [21]. Furthermore, Zhang, et al. [22] suggested that foxtail millet is more water efficient compared to maize and sorghum.

Echniochloa utilis and E. frumentacea are two cultivated species of barnyard millet [23]. Echniochloa utilis is also called Japanese barnyard millet, whereas E. frumentacea has several names such as Indian barnyard millet, sawa millet, and billion-dollar grass. This type of millet is considered a minor cereal and is grown widely in India, China, Japan, Pakistan, Africa, and Nepal [24]. Barnyard millet ranks second in terms of production (87,000 tons per annum) and productivity (857 kg/ha) after finger millet in India [25]. It is a drought-tolerant crop with a rapid maturation rate and possesses high nutritional qualities [26].

Kodo millet originated in India. It is assumed that domestication of this millet took place about 3000 years ago [27,28]. Kodo millet is well suited for tropical and sub-tropical regions [28,29]. Kodo millet is said to possess the highest drought resistance among all minor millets and believed to give good yield with a growing period lasting $80-135$ days [30]. 
Table 1. Scientific names, common names, regions and conditions required for cultivation of different types of Millet around the world.

\begin{tabular}{|c|c|c|c|c|c|}
\hline Type of Millets & $\begin{array}{l}\text { Scientific } \\
\text { Name }\end{array}$ & $\begin{array}{l}\text { Common } \\
\text { Name }\end{array}$ & Cultivated Regions & Growing Conditions & References \\
\hline Pearl Millet & Pennisetum typhoides & Bulrush millet & $\begin{array}{c}\text { Central, Eastern and Southern Africa; in } \\
\text { Western Africa, (Sahel), India and Pakistan } \\
\text { along the southern coast of the Arabian } \\
\text { Peninsula * }\end{array}$ & $\begin{array}{l}\text { Dry climates, marginal soils, Rainfall } \\
\qquad 200-500 \mathrm{~mm}\end{array}$ & $\begin{array}{l}*[11] \\
* *[10]\end{array}$ \\
\hline Finger millet & Eleusine coracona & $\begin{array}{l}\text { Birds food millet or African } \\
\text { millet }\end{array}$ & Parts of India and Africa * & $\begin{array}{l}\text { Resist higher temperatures and salinity, } \\
\text { temperature } 11 \text { to } 27^{\circ} \mathrm{C} \text {, soil } \mathrm{pH} \text { of } 5 \text { to } 8.2 \\
\text { and a medium rainfall environment }\end{array}$ & $\begin{array}{l}*[13] \\
* *[14]\end{array}$ \\
\hline Proso Millet & Panicum miliaceum & $\begin{array}{l}\text { Common millet, hog millet, } \\
\text { broom corn, yellow hog, } \\
\text { hershey and white millet }\end{array}$ & $\begin{array}{l}\text { China, India, Russia, in the Middle East } \\
\text { including Iran, Iraq, Syria, Turkey } \\
\text { Afghanistan and Romania * }\end{array}$ & $\begin{array}{l}\text { Less water, Rainfall less than } 600 \mathrm{~mm} \text {, } \\
\text { average temperature } 17^{\circ} \mathrm{C} \text { during daytime }\end{array}$ & ${ }^{*}[15-17]$ \\
\hline Foxtail Millet & Setaria italica & $\begin{array}{l}\text { Italian millet, German millet, } \\
\text { or hay millet }\end{array}$ & $\begin{array}{l}\text { Europe, China, India, Indonesia, the } \\
\text { Korean peninsula and the former U.S.S.R. * }\end{array}$ & Less water $* *$, short duration ${ }^{* * *}$ & $\begin{array}{c}*[19] \\
* *[20] \\
* * *[22]\end{array}$ \\
\hline Barnyard Millet & $\begin{array}{l}\text { Echinochloa crusgalli var. } \\
\text { Frumentacea or E. colona } \\
\text { (Sawa) }\end{array}$ & - & $\begin{array}{c}\text { India, China, Japan, Pakistan, Africa and } \\
\text { Nepal * }\end{array}$ & Drought tolerant, rapid maturation rate ** & $\begin{array}{l}*[24] \\
* *[26]\end{array}$ \\
\hline Kodo Millet & Paspalum scorbiculatum & - & Tropical and sub-tropical regions * & $\begin{array}{l}\text { High drought resistance, Good yields, } \\
\text { period of } 80-135 \text { days } * *\end{array}$ & $\begin{array}{l}*[28,29] \\
* *[30]\end{array}$ \\
\hline
\end{tabular}




\section{Methodology Adopted}

It can be observed that most of the millets are grown in parts of South America, Europe, Africa, South Asia, Southeast Asia and China (Figure 1). It indicates that these are the regions with suitable climatic conditions to grow millets. This is used as the first criteria for selecting these specific regions in this study. It can be understood that there has been an increase in harvested area for millet in Africa, whereas China, South America, Southern Asia and Europe have shown a downfall in the cultivated area for millet (Figure 2). However, the cultivated area is almost constant for South Asia for the duration of 1961-2016. A higher millet yield (hg/ha) for China, South America, South Asia, Southeastern Asia and Europe can be observed whereas Africa showed almost a constant yield throughout the period (Figure 3). Hence, it can be inferred that though the area under millet cultivation is decreasing in Europe and China, the yield is increasing which suggests a possibility that a consumption demand still exists in these regions. The second criteria were to limit the studies selected to 2012-2018 which can provide updated information. The third criteria for consideration were that each study selected must cover a large geographical area in the selected regions.

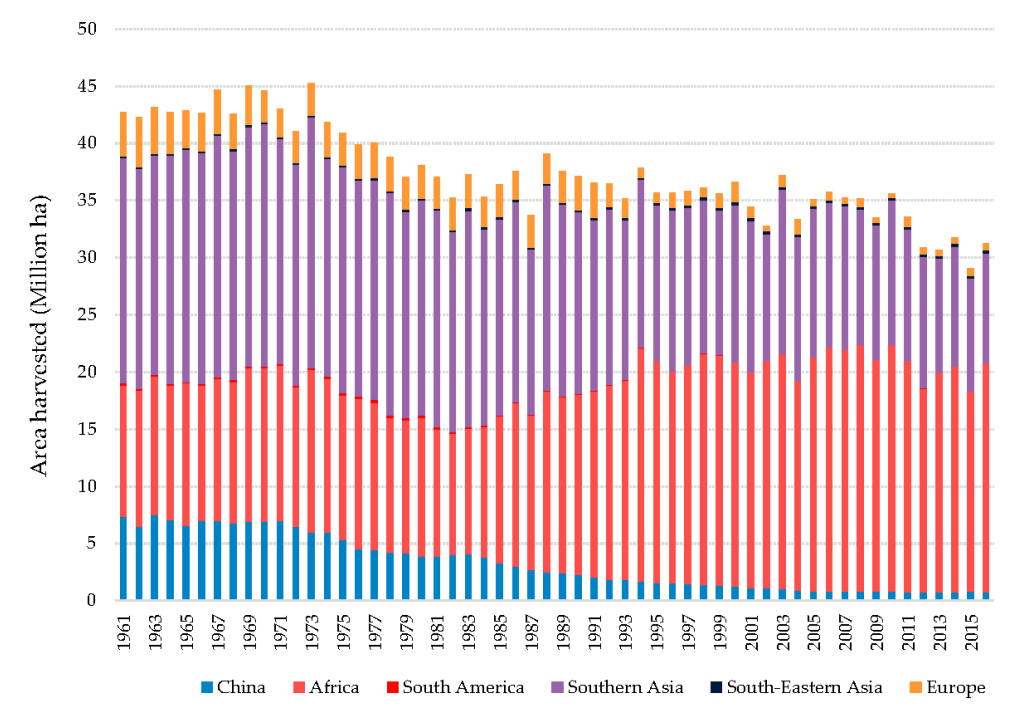

Figure 2. Area under cultivation of Millets in different regions of the world.

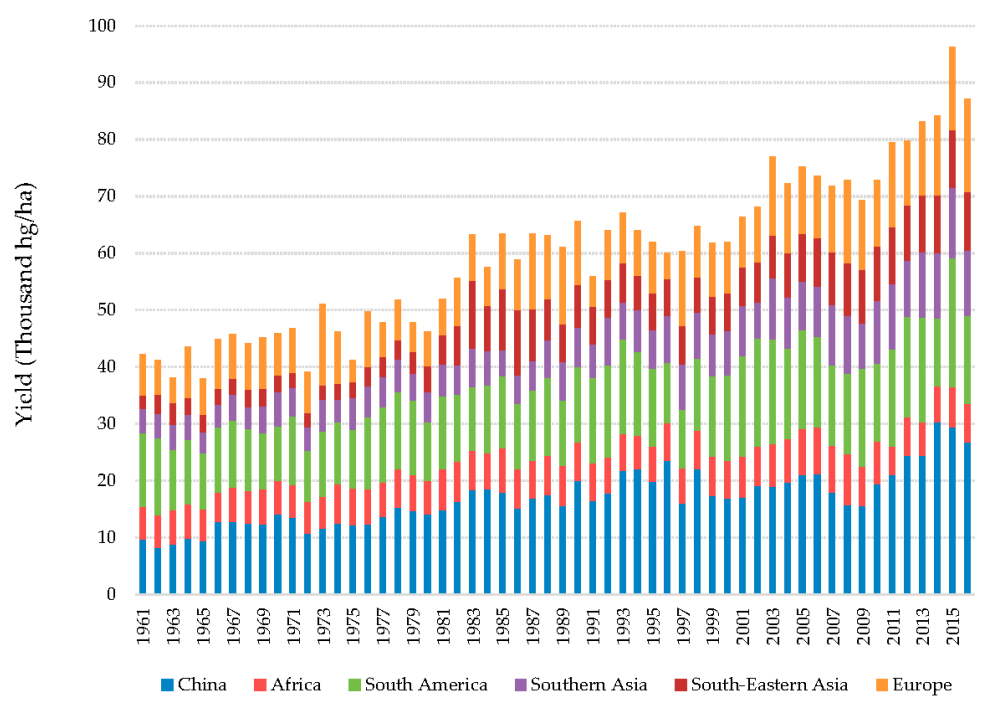

Figure 3. Yield of Millets in different regions of the world. 


\section{Predicted Climate Changes and Crop Productivity}

\subsection{Change in Soil Condition}

Soil security can be defined as maintaining and improving the world's soil resources to provide food, fiber and freshwater [31]. It has been estimated that $97 \%$ of our food comes from the soil and $98 \%$ of terrestrial biodiversity exists within the soil. Today, the quality of the world's soil is decaying gradually, and little is being done to address this issue. An initiative by the United Nations Convention to Combat Desertification (UNCCD) garnered attention as it addresses the issues which can help tackle biodiversity loss and climate change [32].

The current human population of 7.4 billion is estimated to increase to 9.1 billion people by 2050 [3]. Hence, to satisfy the demand of the increasing population of nutritious food, the production rates of food, feed, and fiber must rise drastically. The estimated production rates required to feed a population of 9.1 billion were found to be higher than what they were in the last 5000 years combined [33]. Despite these demands on the ecosystem, an estimated 20-million-acres of arable land in the USA have been lost to development, and the country lost at least one-half of its topsoil (rich in organic matter) over the last two decades [34]. Stott and Moebius-Clune [33] reported that there would be a further decline in ecosystem services resulting in a considerable impact on physical and biological functions in field soils. Over the last two centuries, the organic matter of the soil (containing $58 \%$ of carbon) has been degraded by microbes. During plowing, the soil structure which protects the organic carbon of the soil from microbial attack and erosion is broken apart. Moreover, almost $66 \%$ of the topsoil (A horizon) has been lost which also contributes to the previously mentioned conditions.

Soil erosion is one of the primary cause for the loss of soil quality around the world [35-37]. Factors contributing to soil erosion are soil structure, the role of vegetative cover, land topography and soil disturbances. The soil is eroded gradually but its cumulative impact on soil quality over the years is considerable [38]. The erosion rates vary widely from $0.001 \mathrm{t} / \mathrm{ha} /$ year on flat land having grass or forest cover to $1-5 \mathrm{t} / \mathrm{ha}$ /year in mountainous regions having natural vegetation [39]. It is important to note that, even though the rates of soil erosion are low, they recur over many years and, hence, erosion has an enormous potential to shift a considerable amount of soil [40]. It is estimated that world agricultural systems are losing approximately 75 billion tons of fertile soils every year [41,42]. The data for the world's arable land for land quality classes I-VI show that almost 67 billion tons of soil are eroded by water every year $[38,43]$.

Prediction of soil erosion rates in future are made with the help of soil erosion models. Although it is possible to analyze few catchments and farms to evaluate the current soil erosion rates and project the best management practices, it is nearly impossible to execute such a large-scale study in each specific location to propose future soil erosion rates. Hence, to resolve this problem, soil erosion models are used provided they are robust and used in the right manner [44]. There are multiple models used for erosion modeling such as The European Soil Erosion Model (EUROSEM) [45], Griffith University Erosion System Template (GUEST) [46], The LImburg Soil Erosion Model (LISEM) [47], Revised Universal Soil Loss Equation (RUSLE) [48], Système Hydrologique Européen TRANsport (SHETRAN) [49] and so on. The various scenarios predicted are summarized in Table 2. 
Table 2. Summary of soil erosion predictions from select studies.

\begin{tabular}{|c|c|c|c|}
\hline Regions or Countries & Model/Methodology & Major Findings & References \\
\hline \multicolumn{4}{|l|}{ South America } \\
\hline - $\quad$ Ecuador & Revised Universal Soil Loss Equation & $\begin{array}{l}\text { Maximum erosion rates are estimated for cropland area and } \\
\text { pasture }(936 \mathrm{Mg} / \mathrm{ha} / \text { year) where precipitation rates and slopes } \\
\text { have a higher value } \\
\text { By } 2040 \text {, the soil erosion rates will increase to } 2021 \mathrm{Mg} / \text { ha/year } \\
\text { when the deforestation is maximum in the watershed }\end{array}$ & {$[50]$} \\
\hline - $\quad$ South America & $\begin{array}{l}\text { Soil erosion model (combination of remote sensing, GIS } \\
\text { modeling and census data) }\end{array}$ & $\begin{array}{l}\text { - Increase in soil erosion worldwide due to the expansion } \\
\text { of croplands } \\
\text { During 2001-2012, the estimated increase in soil erosion was } 8 \% \\
\text { due to deforestation and huge cropland expansion in Argentina } \\
(41.6 \%), \text { Brazil }(19.8 \%) \text {, Bolivia }(37.8 \%) \text { and Peru }(5.9 \%)\end{array}$ & [51] \\
\hline \multirow{2}{*}{ - $\quad$ Brazil } & $\begin{array}{l}\text { Water Erosion Prediction Project (WEPP) and climate } \\
\text { generator (CLIGEN) } \\
\text { Geographic Information system (GIS) }\end{array}$ & $\begin{array}{l}\text { Increase in soil erosion rates and runoff rates due to increase in } \\
\text { depths and intensities of rainfall }\end{array}$ & [52] \\
\hline & $\begin{array}{l}\text { Universal Transverse Mercator }(\mathrm{UTM}) \text { and Brazil } \\
\text { Geodesic referencing system }\left(\text { SIRGAS }_{2000}\right)\end{array}$ & $\begin{array}{l}\text { A significant part of the regions shows low potential for surface } \\
\text { runoff and moderate potential for soil erosion rates } \\
\text { - Changes in soil cover accelerate soil erosion }\end{array}$ & [53] \\
\hline \multicolumn{4}{|l|}{ Europe } \\
\hline - Germany & Monitoring of 86 agricultural fields & $\begin{array}{l}\text { - } \quad \text { Average mapped soil loss accounts for } 0.85 \mathrm{t} / \mathrm{ha} / \mathrm{a} \\
\text { - } \\
\text { Maximum yearly soil loss on an individual field was } \\
\text { - } \\
\text { Agricultural practices have a positive influence on soil } \\
\text { erosion rates }\end{array}$ & [54] \\
\hline \multirow[b]{2}{*}{ - $\quad$ Europe } & Revised Universal Soil Loss Equation (RUSLE) & $\begin{array}{l}\text { - Average soil loss in agricultural, forest and semi-arid lands } \\
\text { accounts for } 2.46 \mathrm{t} / \mathrm{ha} \text { /year } \\
\text { - } \quad \text { Annual total soil loss is estimated to } 970 \mathrm{Mt}\end{array}$ & [55] \\
\hline & Rainfall Erosivity Database & $\begin{array}{l}\text { - } \quad \text { Estimated rainfall erosivity in Europe and Switzerland is } \\
722 \mathrm{MJ} \mathrm{mm} / \mathrm{ha} \text { h year } \\
\text { Erosivity density reported were higher in Mediterranean } \\
\text { regions indicating the possibility of soil erosions and floods in } \\
\text { the future }\end{array}$ & [56] \\
\hline
\end{tabular}


Table 2. Cont.

\begin{tabular}{|c|c|c|c|}
\hline Regions or Countries & Model/Methodology & Major Findings & References \\
\hline & Cubist Regression Model & $\begin{array}{l}\text { - K-factor (an indicator of susceptibility to soil erosion) was } \\
0.032 \mathrm{t} \text { ha } \mathrm{h} / \mathrm{ha} \text { MJ mm } \\
\text { - } \\
\text { Decrease in the soil erosivity up to } 15 \% \text { caused by a stone cover } \\
\text { surface over the soil }\end{array}$ & [57] \\
\hline & $\begin{array}{l}\text { European Environment Information and Observation } \\
\text { Network for soil (EIONET-SOIL) }\end{array}$ & $\begin{array}{l}\text { Austria, Belgium, Bulgaria, Germany, Italy, Netherlands, } \\
\text { Poland and Slovakia have a soil erosion rate of } 2.32 \mathrm{t} / \mathrm{ha} / \text { year } \\
\text { - Soil erosion rates were higher for Italy (6.60 t/ha/year) and } \\
\text { lowest for The Netherlands }(0.25 \mathrm{t} / \mathrm{ha} / \text { year })\end{array}$ & [58] \\
\hline \multicolumn{4}{|l|}{ Africa } \\
\hline \multirow{2}{*}{ - West Africa } & Six Regional and Global climate models & $\begin{array}{l}\text { - Ambiguity in the prediction of temperature increase } \\
\text { and precipitation } \\
\text { - Soil erosion rates might increase or decrease depending on the } \\
\text { temperature and precipitation }\end{array}$ & [59] \\
\hline & Land Management and Planning Tool & $\begin{array}{l}\text { - Net soil losses in the years } 1972,1987,2000 \text { and } 2014 \text { were } 26 \text {, } \\
\text { 23, } 27 \text { and } 44 \mathrm{t} / \text { ha /year and the soil loss was higher than the } \\
\text { tolerable limits for the tropics } \\
\text { Management practices such as identifying erosion hotspots } \\
\text { could decrease soil loss in future }\end{array}$ & {$[60]$} \\
\hline East Africa & $\begin{array}{l}5 \mathrm{~km} \times 5 \mathrm{~km} \text { resolution multisource rainfall product } \\
\text { (Climate Hazards Group InfraRed Precipitation } \\
\text { with Stations) }\end{array}$ & $\begin{array}{l}\text { Mean annual rainfall in the region during } 1981-2016 \text { was } 810 \\
\mathrm{~mm} ; 300 \mathrm{~mm} \text { being in the lowland areas and } 1100 \mathrm{~mm} \\
\text { in highlands } \\
\text { - } 55 \% \text { of the region will face rainfall erosivity above the } \\
\text { moderate level } \\
\text { This region will face potential high-water erosion risk in } \\
\text { the future }\end{array}$ & [61] \\
\hline - Sub-Saharan Africa & $\begin{array}{l}\text { Soil erosion model (combination of remote sensing, GIS } \\
\text { modeling and census data) }\end{array}$ & $\begin{array}{l}\text { - Less developed economies such as Sub Saharan Africa has } \\
\text { erosion rates three times more than the developed economies } \\
\text { - The African territories along the equator are the hot spots for } \\
\text { soil erosion (soil erosion rates higher than } 20 \mathrm{Mg} / \mathrm{ha} / \text { year) }\end{array}$ & {$[51]$} \\
\hline
\end{tabular}


Table 2. Cont.

Regions or Countries

- $\quad$ Africa

Global Rainfall Erosivity Database (GloREDa)

Southeastern Asia

Soil erosion model (combination of remote sensing, GIS modeling and census data)

- $\quad$ Southeast Asia

Mann-Kendall statistical test and Theil and Sen's approach

- Southeast Asia

(Laos-Vietnam transnational Soil and Water Assessment Tool (SWAT) Upper Ca River Watershed)

South Asia

Review of various articles

- $\quad$ South Asia
Major Findings

References

- Global mean rainfall erosion rates are estimated to be $2190 \mathrm{MJ} \mathrm{mm} /$ ha h year

- The highest value of erosivity are found in Central east Africa

- $\quad$ Soil erosion is predicted more in Western Africa, Central Africa

- Prediction of increase in soil erosion in the region

- Erosion hot spots are present in Indonesia (0.076 million $\mathrm{km}^{2}$;

- Increase in rainfall erosivity during 1961-2012 with a significant

- High precipitation rates and high warming rates pose a higher

- Climate change will cause more soil erosion in downstream

- Increase in soil erosion in wet climates of the wet season due to

- This region will be hit hard by climate change by the end of the

- Increase in temperature by at least $2{ }^{\circ} \mathrm{C}$ compared to

- Adverse climate conditions will affect soil properties and will

- India showed a slight decrease in erosion rates up to $2 \%$

Soil erosion model (combination of remote sensing, GIS modeling and census data)

- Hot spots of soil erosion are present in India (soil erosion whereas lower values are present in Northern Africa $5 \%$ of the country) increase observed in last two decades risk of soil erosion during the period compared to upstream due to more precipitation high-intensity rainfal 21st century

20th century increase the soil erosion rates greater than $20 \mathrm{Mg} / \mathrm{ha}$ /year)

- India is in the red zone of high rainfall erosivity ( $>4500 \mathrm{MJ} \mathrm{mm} /$ ha h year) ] 
Table 2. Cont.

Regions or Countries Model/Methodology

Geographic Information system (GIS)

- India

Least-square support vector machine (LS-SVM)

Statistical downscaling model (SDSM) models and the

Universal soil loss equation (USLE) model

Revised Universal Soil Loss Equation (RUSLE) model

coupled and transport limited sediment

delivery (TLSD)

Basin, (India)

Major Findings

References

- Annual soil loss increased by $16 \%$ and $61 \%$ as estimated by two different models during 2001-2008

- Anthropogenic activities increased soil erosion in the region during the period

- Climate change will affect the soil erosion rates

- Increase in future precipitation by $18.09 \%$ in 2050 and $58.9 \%$ by 2080

- The rate of change of soil erosion will be $18.09 \%$ in 2050 and $58.9 \%$ in 2080 with a decrease of $8.51 \%$ in 2020

- Average gross soil erosion is $14.36 \mathrm{t} / \mathrm{ha}$ /year and average net soil erosion is $3.60 \mathrm{t} / \mathrm{ha} /$ year

- A major part of the basin has slightly less erosion rates $(<5 \mathrm{t} / \mathrm{ha} /$ year $)$

- Annual soil organic carbon (SOC) content loss sums to $0.42 \mathrm{t}$

- The maximum rate for soil erosion for different lands was: Conventional tillage farmland $\left(94,887 \mathrm{t} / \mathrm{km}^{2} /\right.$ year $)$, bare land $\left(92,423 \mathrm{t} / \mathrm{km}^{2} /\right.$ year$)$, bunch planting $\left(64,670 \mathrm{t} / \mathrm{km}^{2} /\right.$ year $)$ natural grassland $\left(37,794 \mathrm{t} / \mathrm{km}^{2} /\right.$ year $)$.

Analysis of soil erosion rates in fifteen experimental plots

- Minimum soil erosion rates were observed for artificial grassland $\left(21,340 \mathrm{t} / \mathrm{km}^{2} /\right.$ year $)$

- Intensive Land-use tends to accelerate the soil erosion rates in the upstream catchment area

In situ bank gully field flume experiment

- $\quad$ Reduction in tillage practices and increase in vegetation cover could help in reducing soil erosion in upstream catchment areas

Universal Soil Loss Equation (USLE)
- $\quad$ The mean yearly soil erosion rates for river basins Weichenghe and Lizixi is $706 \mathrm{t} / \mathrm{km}^{2} /$ year and $3040 \mathrm{t} / \mathrm{km}^{2} /$ year

- High erosion rates are due to high altitudes and intensive use of agricultural land 


\subsection{Depletion of Water Resources}

Most of the studies conducted on the future of the world's water resources are concentrated on "blue water" found in lakes, reservoirs, rivers and aquifers [72-75]. To assess the actual water resources available for the population, it is important to consider "green water" [76]. Green water is defined as rainwater that infiltrates the soil [77] and is responsible for the sustainable growth of all terrestrial ecosystems and is used in the majority of agricultural activities [78,79]. It was also assumed by Rockström et al. [80] that countries having less than 1300 cubic meters per capita per year of total green and blue waters would not be able to produce a balanced diet of $3000 \mathrm{kCal}$ per capita per day. This value was also endorsed by the FAO (Food and Agricultural Organization) as the goal that all developing countries are supposed to reach by 2030 [81].

Almost 2 billion people across the world do not have access to water and henceforth food production, economic development, human health and ecosystem services are hampered. Water scarcity can cause groundwater depletion which might lead to irreversible land subsidence, urban water shutoffs, wildfires and crop failure. Factors such as an increase in population and climate change contribute to water scarcity [82]. MacDonald [83] suggests that climate models projected an increase in the number of droughts in the 21st century in South Western United States which will be more arid, severe and remain for longer periods of time. The increase in population demands more food but the food production would remain the same. This will lead to food insecurity in the future [84].

A hydrological model is defined as a system or a prototype which represents the whole world in a simplified form. These models are used to analyze system behavior and to understand the hydrological processes. The parameters involved define the characteristics of the model. Rainfall data and area of drainage are the two necessary inputs needed for all models. The other important factors considered for modeling are groundwater aquifer characteristics, the topography of the watershed, soil moisture content, and watershed characteristics such as vegetation cover and soil properties. Hydrological models are thus considered as a vital tool to manage water, and environmental resources $[85,86]$ and the summarized predictions of water scenario are presented in Table 3. 
Table 3. Summary of predicted water resources in the future based on selected studies.

\begin{tabular}{lcc}
\hline \multicolumn{1}{c}{ Regions or Countries } & Model & Major Findings \\
\hline South America & & References \\
\hline
\end{tabular}

- Detection of water loss rate of $-6.1 \mathrm{~cm} /$ year over

CLM, Mosaic, Noah, VIC

- The precipitation rates will lower due to extreme droughts in the region

- Persistent reduction in precipitation rates to $20-23 \%$ over three years could lead to water scarcity conditions

- Reduction in value of recharge in Northeast region aquifers by $70 \%$ by 2050 compared to 2010 . This value will vary from 30 to $70 \%$ in North region

Review of various research articles

- South and the southeastern region will have an increase in recharge of aquifers from $30 \%$ to $100 \%$

- Increase in population and demand for water availability will make aquifers as a main source of water supply and hence leading to water scarcity in future

- Andean Region

- Bolivia
Collection of rainfall data from various resources

Global Circulation Model (GCM)

- $\quad$ Regions having variability in seasonal rainfall will face water scarcity but not those where annual rainfall is lower

- Increase in temperature $\left(2.5-5.9^{\circ} \mathrm{C}\right)$ and short-wave radiation predicted for duration 2070-2099

- Less rainfall $(-19 \%)$ in drier months with some variations in inter-annual rainfall

- Major expansion of arid lands in Southern America

- South American region

27 Global climate models

- Increase in the population affected by land degradations and water scarcity

- Central and Southern Andes of Data collection from research projects South America

- Hundreds of millions of people will face water crisis by 2020 due to climate change. The reason being melting of glaciers, reduction in snowpack and precipitation

Europe

- Mediterranean region (Llobregat River basin, Spain)

InVEST (Integrated Valuation of Ecosystem Services and Tradeoffs)

- Hydrological ecosystem services are in the red zone due to increase in population and extreme climate changes

- $\quad$ Mediterranean region (Francoli InVEST (Integrated Valuation of Ecosystem River basin, Spain)

- Water yield will reduce to up to $44 \%$, and total drinking water availability will decrease up to $50 \%$ by 2100 
Table 3. Cont.

Regions or Countries

- $\quad$ European Union

EXIOBASE

- $\quad$ Southern Area of Italy

TOPDM (Topography based probability distribution model)

- Semi-arid Segura basin (Southeast Spain)

Energy balance models

- $\quad$ European Cities

City Blueprint Methodology

\section{Major Findings}

References

- The Indus and Mississippi watersheds (the watersheds responsible for water consumption in Europe) will cause significant environmental impacts because of water scarcity in both the watersheds

- More stress on water resources in the future (by 2100) due to a decrease in precipitation.

- Water management practices should be addressed adequately to avoid water scarcity

- The probability of reduction in water availability by $40 \%$ in the worst case with an economic impact ranging 32-36\%

- Evaporation loss from reservoir account for 6.5 to $11.7 \%$ and evaporation from the small basin is more compared to large basins.

- Most European cities fall into the category of water-efficient cities and resource efficient and adaptive cities. However, proper planning is required to make cities water-wise and to avoid water scarcity in the future

$$
\text { Africa }
$$

- North and South Africa

Global Climate Models

- $\quad$ Four sizeable African river basins (the Niger, the Upper Blue Nile, the Oubangui and the Limpopo)

- Sub-Saharan Africa

SWIM (Soil and water integrated model)

- North Africa

Sequential Maximum A Posteriori Classifier' (SMAPC)

MAgPIE (model of agricultural production and its impact on world)

- $\quad$ Africa

Water Poverty mapping
- Expansion of arid regions in future and semi-arid regions in North side of the Mediterranean, Southern Africa

$[91$

- Increase in discharge and high flows in Upper Blue Nile Basin which indicates frequent flooding in future

- Flood threat in the African region

- The implication of monitoring strategies and land use planning as there will be an increase in water scarcity in African region in future

- Rise in water scarcity in the region by 2045. Even new made policies would not be able to retain water scarcity

- Water scarce and developed countries are in North and South Africa whereas water-rich and lower income countries are in Sub-Saharan Africa 
Table 3. Cont

\begin{tabular}{|c|c|c|c|}
\hline Regions or Countries & Model & Major Findings & References \\
\hline - $\quad$ Lhasa River basin & $\begin{array}{l}\text { PROMET (Processes of Radiation, Mass and } \\
\text { Energy transfer) and SURGES (Subscale } \\
\text { Regional Glacier Extension Simulator) }\end{array}$ & $\begin{array}{l}\text { - Ice melt contribution to total runoff will be stable with small } \\
\text { variations by } 2080 \\
\text { Decrease in contribution to runoff by snowmelt due to global } \\
\text { climate change }\end{array}$ & [103] \\
\hline - $\quad$ South Asia & $\begin{array}{l}\text { MAgPIE (model of agricultural production } \\
\text { and its impact on world) }\end{array}$ & $\begin{array}{l}\text { - Increase temperature with increase in evaporation will reduce } \\
\text { water availability } \\
\text { - } \quad \text { Rise in water scarcity in the region by } 2045\end{array}$ & [101] \\
\hline - $\quad$ South Sulawesi, Indonesia & Review of various documents & $\begin{array}{l}\text { - Water scarcity will be a major problem for local communities } \\
\text { in future } \\
\text { - Several factors such as increasing no. of wells, rise in population } \\
\text { and unavailability of water management institutes will affect } \\
\text { water scarcity }\end{array}$ & [104] \\
\hline Indonesia & Water sustainability hierarchy model & $\begin{array}{l}\text { - } 37 \text { million people do not have access to safe water due to issues in } \\
\text { water quality }\end{array}$ & [105] \\
\hline \multicolumn{4}{|l|}{ Southern Asia } \\
\hline \multirow[t]{2}{*}{ - $\quad$ South Asia } & $\begin{array}{l}\text { Assessment of blue water scarcity globally } \\
\text { on a monthly basis }\end{array}$ & $\begin{array}{l}\text { - Pakistan faces moderate to severe water scarcity during at least half } \\
\text { of the year } \\
\text { - India faces high water scarcity } \\
\text { - } \quad \text { Depletion of ground water resources in India Pakistan } \\
\text { during (streamflow drought index) shows a declining trend } \\
\text { during }\end{array}$ & [106] \\
\hline & $\begin{array}{l}\text { Literature review of various policies } \\
\text { and documents }\end{array}$ & $\begin{array}{l}\text { - } 70 \% \text { of the population depends on agriculture for livelihood and } \\
\text { agriculture contributes to } 22 \% \text { of GDP (Gross domestic product) } \\
\text { Reduction in arable land due to water scarcity, rise in sea level, } \\
\text { flooding, increased intensity and frequency of storm }\end{array}$ & [107] \\
\hline - India (Tapi river basin) & Temporal analysis and spatial mapping & $\begin{array}{l}\text { - Quality of water was deteriorated in the same period and in turn } \\
\text { lead to water scarcity for the nearby population } \\
\text { - Water scarcity is anticipated to increase by } 2095\end{array}$ & [108] \\
\hline - India & GCAM (Global Change Assessment Model) & $\begin{array}{l}\text { - The increasing population will never be able to meet water } \\
\text { demands in the future } \\
\text { - } \quad \text { Dependency on water reuse, desalinated water } \\
\text { - High-risk water scarcity in the agricultural area of } 6.3 \% \text {, high water } \\
\text { scarcity in } 19.1 \% \text { area and moderate water risk in } 37.2 \% \text { area }\end{array}$ & [109] \\
\hline
\end{tabular}


Table 3. Cont

\begin{tabular}{|c|c|c|c|}
\hline Regions or Countries & Model & Major Findings & References \\
\hline - $\quad$ Bangladesh & $\begin{array}{l}\text { Catastrophe-theory based multi-criteria } \\
\text { decision }\end{array}$ & $\begin{array}{l}\text { Water unavailability in Northwest region and degraded water } \\
\text { quality in Southwest region are responsible for water scarcity in } \\
\text { these regions. }\end{array}$ & [110] \\
\hline \multicolumn{4}{|l|}{ China } \\
\hline & LCA (Life cycle assessment) & $\begin{array}{l}\text { - Significant change in green water flow occurring in Central regions } \\
\text { of China }\end{array}$ & [111] \\
\hline & MRIO (Multi-Regional input-output model) & $\begin{array}{l}\text { - Perturbations occurring in surface blue water in Central China } \\
\text { - The three reaches of Yellow River basin are net exporter of virtual } \\
\text { blue water and hence putting pressure on the basin activities }\end{array}$ & [112] \\
\hline & MRIO (Multi-Regional input-output model) & $\begin{array}{l}\text { - } \quad \text { Lower reach is the scarcest water region } \\
\text { Coastal provinces are dependent on Northern province for } \\
\text { consumption of water and hence causing water scarcity in } \\
\text { Northern region } \\
\text { - Highly developed province is net importer of water which causes } \\
\text { an imbalance of distribution of water resources. }\end{array}$ & [113] \\
\hline
\end{tabular}




\subsection{Effect of Climate Change on Agricultural Productivity}

Food consumption represented by $\mathrm{kcal} /$ person/day acts as a criterion to analyze the status of the food situation around the world. The food consumption has increased from $2360 \mathrm{kcal} /$ person/day in 1960 to $2800 \mathrm{kcal} /$ person/day currently. To date, seven developing countries around the world have a population of more than 100 million. Among them, Bangladesh is the only country which remains to have a low food consumption rate. Other countries on the list such as Brazil, China and Indonesia have consumption rates in the range of 2900-3000 kcal, whereas India, Nigeria and Pakistan have also made a good transition to improve their consumption rates. Moreover, almost 30 developing countries around the world have food consumption rates of less than $2200 \mathrm{kcal} /$ person/day [114]. According to FAO (2015), in recent years, one fourth of the disasters occurring from climate changes have affected the agricultural sector badly in these developing countries. The predicted changes in the agricultural productivity are summarized in Table 4.

Lesk et al. [115] reported that, during recent years, the production of cereal crops has been affected by $9-10 \%$ due to adverse climatic conditions such as drastic increase in temperature, drought and so on. The South Asia and Sub-Saharan Africa regions will be accommodating additional 2.4 billion people by the end of 2050. Majority of the population living in these areas depends on the agricultural sector for their survival and livelihood. Right now, more than $20 \%$ of the population living in these regions barely have enough food to meet their demands and the situation will be even worse in coming years. It is recommended that agricultural production should be increased by $60 \%$ by 2050 to meet the food demand of the increasing population. Hence, the focus should be on improving agricultural productivity which in turn will increase income in developing countries [116]. 
Table 4. Effect of climate change on agricultural productivity by 2050.

\begin{tabular}{|c|c|c|c|}
\hline Regions or Countries & Model/Methodology & Major Findings & References \\
\hline \multicolumn{4}{|l|}{ South America } \\
\hline \multirow{4}{*}{ - $\quad$ South America } & Earth system model & $\begin{array}{l}\text { - The possibility of expansion of total cropland area } \\
\text { - With } \mathrm{CO}_{2} \text { fertilization effect, few agricultural areas have to be } \\
\text { abandoned due to low productivity } \\
\text { Without the } \mathrm{CO}_{2} \text { fertilization effect, no effect on the expansion } \\
\text { of cropland }\end{array}$ & [117] \\
\hline & CLM (community land model) & $\begin{array}{l}\text { - } \\
\text { - } \quad \text { decline in the crop yield } \\
\text { - Increase in irrigation requirements up to } 23 \% \text { for } \mathrm{C} 4 \text { crops without } \mathrm{CO}_{2} \\
\text { fertilization and } 3 \% \text { for } \mathrm{C} 4 \text { crops with } \mathrm{CO}_{2} \text { fertilization }\end{array}$ & [118] \\
\hline & $\begin{array}{l}\text { Global Standardized Precipitation } \\
\text { Evapotranspiration Index dataset }\end{array}$ & $\begin{array}{l}\text { - Increase in the global drought-prone area from } 16.19 \% \text { in } 1902-1949 \text { to } \\
41.09 \% \text { in } 950-2008 \\
\text { - South America is one of the regions where agricultural lands are } \\
\text { predicted to be drought-prone }\end{array}$ & [119] \\
\hline & Agricultural drought hazard index (DHI) & $\begin{array}{l}\text { - } 23.57 \% \text { and } 27.19 \% \text { of the total agricultural area in the world comes } \\
\text { under high and very high agricultural drought hazard zones } \\
\text { - These regions are also present in South America } \\
\text { - High agricultural drought hazard zone for crops such as maize, wheat, } \\
\text { soybean and sorghum }\end{array}$ & [120] \\
\hline \multicolumn{4}{|l|}{ Europe } \\
\hline - Central Europe & CERES-Wheat crop-growth simulation model & $\begin{array}{l}\text { - Crop-growing period will be cut short by } 20 \text { days with an increase in } \\
\text { temperature of } 2{ }^{\circ} \mathrm{C} \\
\text { - } \quad \begin{array}{l}\text { Decrease in yield of winter wheat irrespective of the soil types in } \\
\text { all regions }\end{array} \\
\text { - } \quad \text { Prediction of high yield reductions in light textured crops }\end{array}$ & [121] \\
\hline $\begin{array}{l}\text { - Central and } \\
\text { Eastern Europe }\end{array}$ & Different crop models and pest models & $\begin{array}{l}\text { Increase in yield potential in wetter and cooler regions compared to } \\
\text { drier and warmer regions } \\
\text { - Crop yield will be limited by factors such as availability of crop water } \\
\text { and drastic increase in temperature } \\
\text { - Variation in crop yield but it will increase by end of 21st century }\end{array}$ & [122] \\
\hline
\end{tabular}


Table 4. Cont.

\begin{tabular}{|c|c|c|c|}
\hline Regions or Countries & Model/Methodology & Major Findings & References \\
\hline \multirow[t]{2}{*}{ - $\quad$ Europe } & Systematic review and meta-analysis of data & $\begin{array}{l}\text { - Extensive impact of climate change on crop yield for crops such as } \\
\text { maize, potato, sugar beet and wheat while limited impact on barley, } \\
\text { rice and wheat } \\
\text { There will be a reduction in crop yield drastically for maize and potato } \\
\text { in Central and Southern Europe by } 2080\end{array}$ & [123] \\
\hline & RCM (Regional Climate Models) & $\begin{array}{l}\text { Deterioration of length of growing season and potential crop yield due } \\
\text { to excessive summer drying } \\
\text { - } \quad \text { Projected decrease in average crop yield }\end{array}$ & [124] \\
\hline \multicolumn{4}{|c|}{ 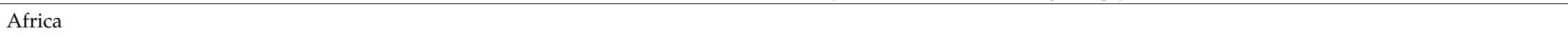 } \\
\hline \multirow{2}{*}{ - West Africa } & Crop Models & $\begin{array}{l}\text { - Decrease in yields of Millets and sorghum in the future } \\
\text { - Increase in the variability of the crop yield } \\
\text { - } \quad \text { Frequency of crop failure will be increased due to increase in } \\
\text { variability of crop yield } \\
\text { - } \quad \text { Fall in return time for crop failure for maize, millets and sorghum }\end{array}$ & [125] \\
\hline & $\begin{array}{l}\text { CMIP5 climate models and two crop models } \\
\text { (SARRA-H and APSIM) }\end{array}$ & $\begin{array}{l}\text { - The projected increase in mean temperature by }+2.8^{\circ} \mathrm{C} \text { during } \\
2031-2060 \text { compared to } 1961-1990 \\
\text { - Yields will decrease up to } 20 \% \text { without } \mathrm{CO}_{2} \text { fertilization and up to } 10 \% \\
\text { with } \mathrm{CO}_{2} \text { fertilization } \\
\text { - Overall, the negative impact of climate on crop yield even with } \\
\mathrm{CO}_{2} \text { fertilization }\end{array}$ & [126] \\
\hline \multirow[t]{2}{*}{ - $\quad$ Africa } & CLM (community land model) & $\begin{array}{l}\text { - Decrease in crop yield up to } 3 \mathrm{t} / \mathrm{ha} \text { in parts of tropical and sub-tropical } \\
\text { Africa due to increase in temperature } \\
\text { - Possibility of mitigation of yield loss by irrigation and } \mathrm{CO}_{2} \\
\text { fertilization effect } \\
\text { - Increase in global irrigation requirements for } \mathrm{C} 4 \text { crops is } 23 \% \text { (without } \\
\mathrm{CO}_{2} \text { fertilization) and } 3 \% \text { (with } \mathrm{CO}_{2} \text { fertilization) }\end{array}$ & [118] \\
\hline & Systematic review and meta-analysis of data & $\begin{array}{l}\text { - Crop yield will show a decline by }-8 \% \text { by } 2050 \\
\text { - The average yields for wheat, maize, sorghum and millet will change } \\
\text { by }-17 \%,-5 \%,-15 \% \text { and }-10 \% \text {, respectively }\end{array}$ & [127] \\
\hline
\end{tabular}


Table 4. Cont

\begin{tabular}{|c|c|c|c|}
\hline Regions or Countries & Model/Methodology & Major Findings & References \\
\hline - $\quad$ Sub-Saharan Africa & $\begin{array}{l}\text { Random Forest (a diagnostic machine } \\
\text { learning technique) }\end{array}$ & $\begin{array}{l}\text { - Increase in temperature reduce yields of groundnut, maize and } \\
\text { sorghum whereas precipitation helped in elevating the crop yield rate } \\
\text { from 1962-2014 } \\
\text { - Improvement in technology helped in increasing maize yields by } 1 \% \\
\text { whereas an increase in temperature reduced the yields by } 0.8 \% \\
\text { Future yield would be affected by increasing temperature and drier } \\
\text { climates, but improvement in technology might help in increasing the } \\
\text { crop yield rate }\end{array}$ & [128] \\
\hline \multicolumn{4}{|l|}{ Southeastern Asia } \\
\hline - Indonesia & $\begin{array}{l}\text { Model of Shierary rice with Geographical } \\
\text { Information system (GIS) }\end{array}$ & $\begin{array}{l}\text { - Increase in temperature would make age of rice shorter and have } \\
\text { negative impact on the rice yields } \\
\text { Irrigated farm }\left(11.1 \% /{ }^{\circ} \mathrm{C}\right) \text { showed less reduction in crop yield } \\
\text { compared to rainfed farms }\left(14.4 \% /{ }^{\circ} \mathrm{C}\right)\end{array}$ & [129] \\
\hline & Aqua crop & $\begin{array}{l}\text { - Droughts occurring at reproductive stages of maize caused highest } \\
\text { maize yield loss }\end{array}$ & [130] \\
\hline - $\quad$ Thailand & $\begin{array}{l}\text { (SPEI) Standardized Precipitation and } \\
\text { Evapotranspiration Index }\end{array}$ & $\begin{array}{l}\text { - Yield loss are in the range of less than } 50 \mathrm{~kg} / \mathrm{ha} \text { per decade } \\
\text { - Interference of increasing temperatures during crop growing season } \\
\text { will negatively affects the crop yield }\end{array}$ & [131] \\
\hline - $\quad$ Myanmar & $\begin{array}{l}\text { Food security Index and food } \\
\text { decomposition method }\end{array}$ & $\begin{array}{l}\text { - The increase in production in the region during 1990-2013 was due to } \\
\text { increase in production area and increase in consumption growth was } \\
\text { mainly due to high requirement of growth per area } \\
\text { - Improvement in irrigation facilities should be needed to avoid food } \\
\text { insecurity in future decades }\end{array}$ & [132] \\
\hline \multicolumn{4}{|l|}{ Southern Asia } \\
\hline \multirow[t]{2}{*}{ - $\quad$ South Asia } & Systematic review and meta-analysis of data & $\begin{array}{l}\text { - Yield reduction of }-8 \% \text { by } 2050 \text { for major crops } \\
\text { - Prediction in reduction of yield of maize by }-16 \% \text { and sorghum } \\
\text { by }-11 \% \\
\text { - No concrete predictions for cassava, sugarcane and yams }\end{array}$ & [127] \\
\hline & Earth system model & $\begin{array}{l}\text { - } \quad \text { Crop yield will decrease without } \mathrm{CO}_{2} \text { fertilization effect } \\
\text { - } \quad \text { Ensuring food security in South Asia will be highly difficult }\end{array}$ & [117] \\
\hline - Pakistan & $\begin{array}{l}\text { Stage stochastic production frontier (SPF) } \\
\text { models, second-stage ordinary least square } \\
\text { (OLS) and quantile regression models }\end{array}$ & $\begin{array}{l}\text { Increase in temperature up to } 34^{\circ} \mathrm{C} \text { will significantly decrease the } \\
\text { economic efficiency of wheat production } \\
\text { Increase in temperature more than } 35.5^{\circ} \mathrm{C} \text { will have adverse effects on } \\
\text { the production of rice }\end{array}$ & [133] \\
\hline
\end{tabular}


Table 4. Cont.

\begin{tabular}{|c|c|c|c|}
\hline Regions or Countries & Model/Methodology & Major Findings & References \\
\hline - India and Bangladesh & $\begin{array}{l}\text { Food security Index and food } \\
\text { decomposition method }\end{array}$ & $\begin{array}{l}\text { - Increase in production during } 1990-2013 \text { was due to increase in crop } \\
\text { yield and increase in consumption of grains was due to } \\
\text { population growth } \\
\text { Advancement of irrigation technologies to ensure food security in the } \\
\text { region in future decades }\end{array}$ & [132] \\
\hline - India & $\begin{array}{l}\text { Decision Support System for Agrotechnology } \\
\text { Transfer (DSSAT) }\end{array}$ & $\begin{array}{l}\text { Increase in reduction in crop yield and shortening of crop growing } \\
\text { period due to rise in temperature } \\
\text { Increase in rainfall might decrease requirement of irrigation water but } \\
\text { would not be able to compensate the negative effect of } \\
\text { rising temperature }\end{array}$ & [134] \\
\hline \multicolumn{4}{|l|}{ China } \\
\hline & $\begin{array}{l}\text { Study of different regions and crops and } \\
\text { collection of data from China's } \\
\text { Agricultural statistics }\end{array}$ & $\begin{array}{l}\text { - Increase in temperature resulted in lower yields of both rice and wheat } \\
\text { between } 1980 \text { and } 2008 \\
\text { - } \quad \text { Higher temperature in turn lower precipitation in Northern parts of } \\
\text { China suggesting reduced yields due to paucity of water resources }\end{array}$ & [135] \\
\hline & $\begin{array}{l}\text { CERES crop models along with the IPCC SRES } \\
\text { A2 and B2 scenarios considering } \mathrm{CO}_{2} \\
\text { fertilization effect }\end{array}$ & $\begin{array}{l}\text { - Increase in food yield up to }+11 \% \text { (A2 scenario) and }+4 \% \text { (B2 scenario) } \\
\text { - Crop production will be } 572 \text { (A2 scenario) and } 615 \mathrm{MT} \text { (B2 scenario) by } \\
2030 \text { and } 635 \text { (A2 scenario) and } 646 \mathrm{MT} \text { ((B2 scenario) by } 2050 \\
\text { - Food security index (FSI) will show an increment of }+7.1 \% \text { (A2 } \\
\text { scenario) and }+20 \% \text { (B2 scenario) }\end{array}$ & [136] \\
\hline & $\begin{array}{l}\text { Five global climate models and A1F1 and B1 } \\
\text { (greenhouse gases emission scenarios) }\end{array}$ & $\begin{array}{l}\text { - Increase in wheat yield up to } 34.4 \% \text { by } 2080 \text { irrespective of } \mathrm{CO}_{2} \\
\text { fertilization effect in North China Plain } \\
\text { - Climate change would have positive impact on the productivity of } \\
\text { winter wheat }\end{array}$ & [137] \\
\hline & $\begin{array}{l}\text { Global Climate Model (GCM) and } \\
\text { WheatGrow Model }\end{array}$ & $\begin{array}{l}\text { - } \quad \text { Reduction in wheat yield in Northern part of China and increase in } \\
\text { wheat yield in South part of China under rainfed conditions } \\
\text { - Increase in wheat yields in all regions under full-irrigation conditions } \\
\text { - Improvement in irrigation facilities would help alleviating food } \\
\text { insecurity issues }\end{array}$ & [138] \\
\hline
\end{tabular}




\section{Outlook}

From the analysis presented in the previous sections, it is evident that not only developing countries but also developed countries will also have to cope with changing climatic conditions. There are a handful of options that can reduce the stress in India, China, and Sub-Saharan Africa which are most affected by climate change. First, they can import food commodities from countries with enough water resources and fertile lands that are producing surpluses. However, this may cause a trade imbalance and negatively affect the GDP and economy of the country. Furthermore, the exporting countries will have to increase crop yields thereby causing additional stress on resources available leading to accelerated depletion. Looking at some predictions, climate change could cause an increase in yields in a few countries; however, this would not be substantial enough to ensure global food security. Countries such as India and China, where a significant proportion of the population relies on agriculture for their livelihood, the loss of income would cause further poverty which would affect the GDP.

The second option is to change the policy of the governments in how they manage the resources that are currently available. Support for water-intensive crops such as rice should be phased out, and the cultivation of alternatives that require less resource should be encouraged. The transition may be gradual as the population slowly changes its diet with proper inputs from the markets as governments push for consumer education and the establishment of a commitment to conservation of resources for future generations. As the population comes to understand that continuing the current agricultural practices, dietary habits, and lifestyles will threaten the survival of the coming generations in many aspects, this will help to encourage change as a viable alternative.

The question arises: What can be done to mitigate such adverse effects? There are many answers to this crucial question. It can be observed that production of major crops such as maize, wheat and rice is increasing around the world (with few exceptions), whereas other crops such as barley, millet, rye and sorghum show increasing or decreasing trends depending on the region (Figure 4). This Figure clearly shows that millets or other low-resource intensive crops can be grown in almost every part of the world. Millet is a drought-resistant crop, requires less water for its growth and possesses high nutritional value compared to other cereal crops such as rice and wheat $[9,20]$. It is difficult for the present population to adopt millets as a food in their diet but if proper initiatives are taken by governments through workable policies considering the seriousness of the situation, it can emerge as a crop having enormous potential to feed the growing population. Millets can be grown in adverse conditions and thus will be able to save farmers and the agri-food industry from losses. It is not a water-intensive crop, and hence a lack of irrigation infrastructure in poor economies of Asia and Africa is not a hurdle to adopt cultivation of this crop. It can be grown in the drier soil. Thus, tillage practices can be avoided reducing the duration of cultivation $[10,18]$.

Millet has an excellent nutritional profile and is a non-glutinous food. This makes them easily digestible and non-allergenic foods. Polished rice produces a high percentage of glucose which is not beneficial for diabetic patients, whereas millet as a food commodity releases low volume of glucose, thus making it safer for consumption by diabetic patients. Millets are rich in phosphorous, potassium, iron, and magnesium. Finger millet has a calcium content that is ten times higher than in rice or wheat [139]. India is the larger producer of millet globally [140]. Small millets such as finger millet and Kodo millet can be grown in adverse climatic and soil conditions. Varieties of millets with short growing duration can be incorporated in multiple cropping systems under irrigated and dry farming conditions $[14,30]$. Moreover, millets can be stored for a considerable amount of time under appropriate storage conditions, therefore making them "famine reserves" [141].

In India, 15.48 million hectares is dedicated to the production of millet with a crop yield of $1111 \mathrm{~kg} / \mathrm{ha}$, producing around 17.2 million tons of millet. The contributions of this crop to overall food grain production has reduced significantly from $22.17 \%$ to $6.94 \%$ between $1950-1951$ and 2011-2012 [141,142]. Malathi, Appaji, Reddy, Dattatri and Sudhakar [142] studied the growth pattern of millets in India. The study concluded that there had been a significant decline in the area allotted 
for the cultivation of millets over the last few decades. The primary reason for this decline could be the government policies favoring production of major cereals such as rice and wheat, and of crops such as oilseeds, cotton, fruits and vegetables. However, despite these issues, the area-wise production of finger millets rose by $47.41 \%$ with crop yields increasing by $147.49 \%$, whereas productivity of pearl millet increased by $247.48 \%$ with an increase in crop yield of $255.61 \%$. Thes data suggest that, even though the area under production of millets has been significantly reduced, crop yield has been increasing.

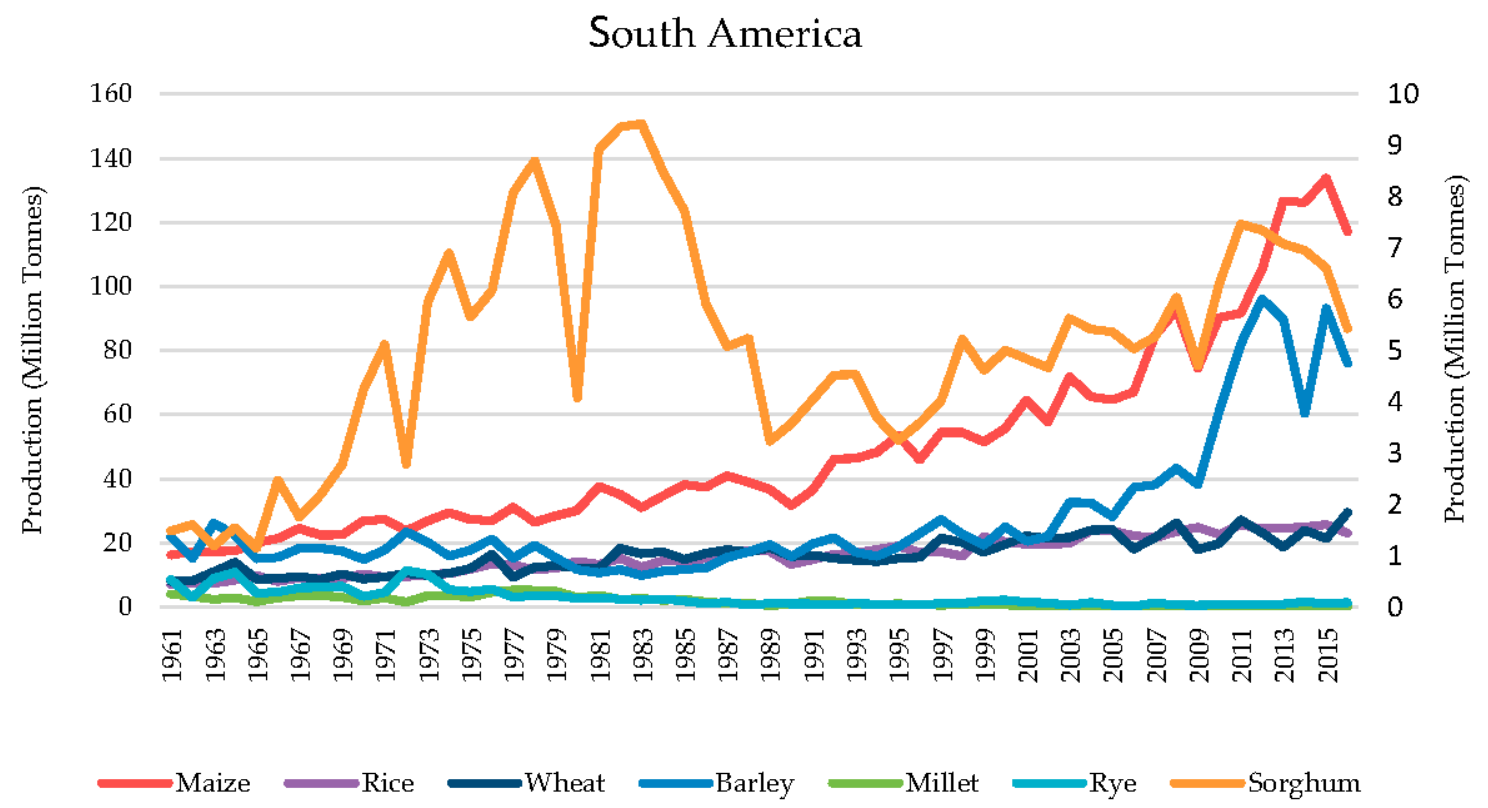

\section{Europe}

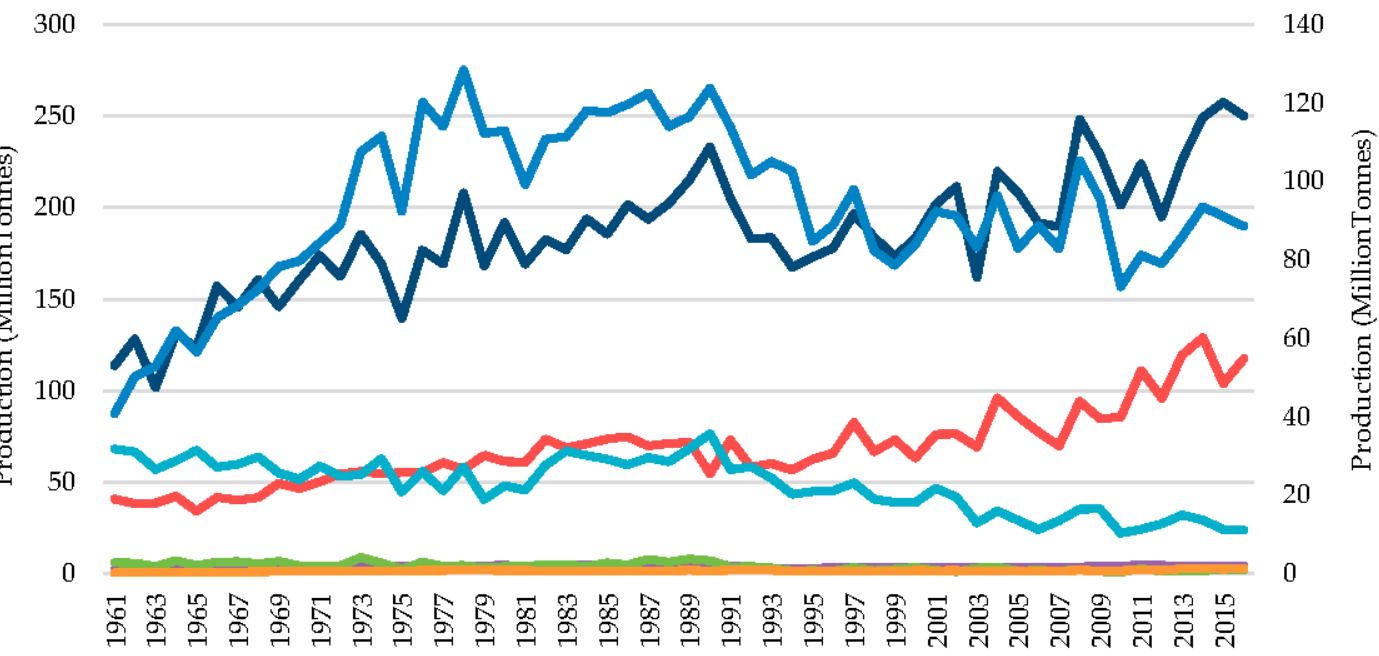

Maize $\longrightarrow$ Rice $\longrightarrow$ Wheat $\longrightarrow$ Barley $\longrightarrow$ Millet $\longrightarrow$ Rye $\longrightarrow$ Sorghum

Figure 4. Cont. 


\section{Africa}

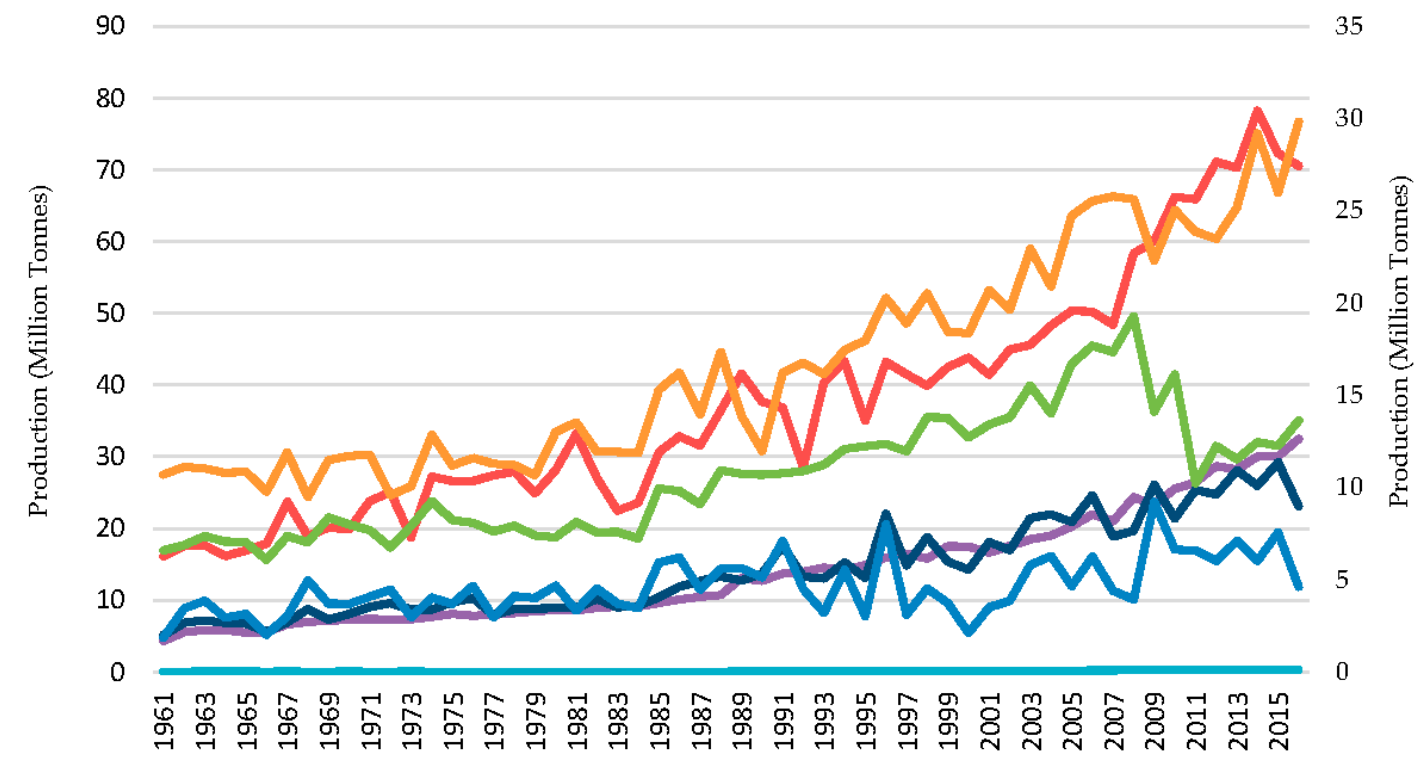

Maize $\longrightarrow$ Rice Wheat $\longrightarrow$ Barley $\longrightarrow$ Millet $\longrightarrow$ Rye $\longrightarrow$ Sorghum

South Eastern Asia

250

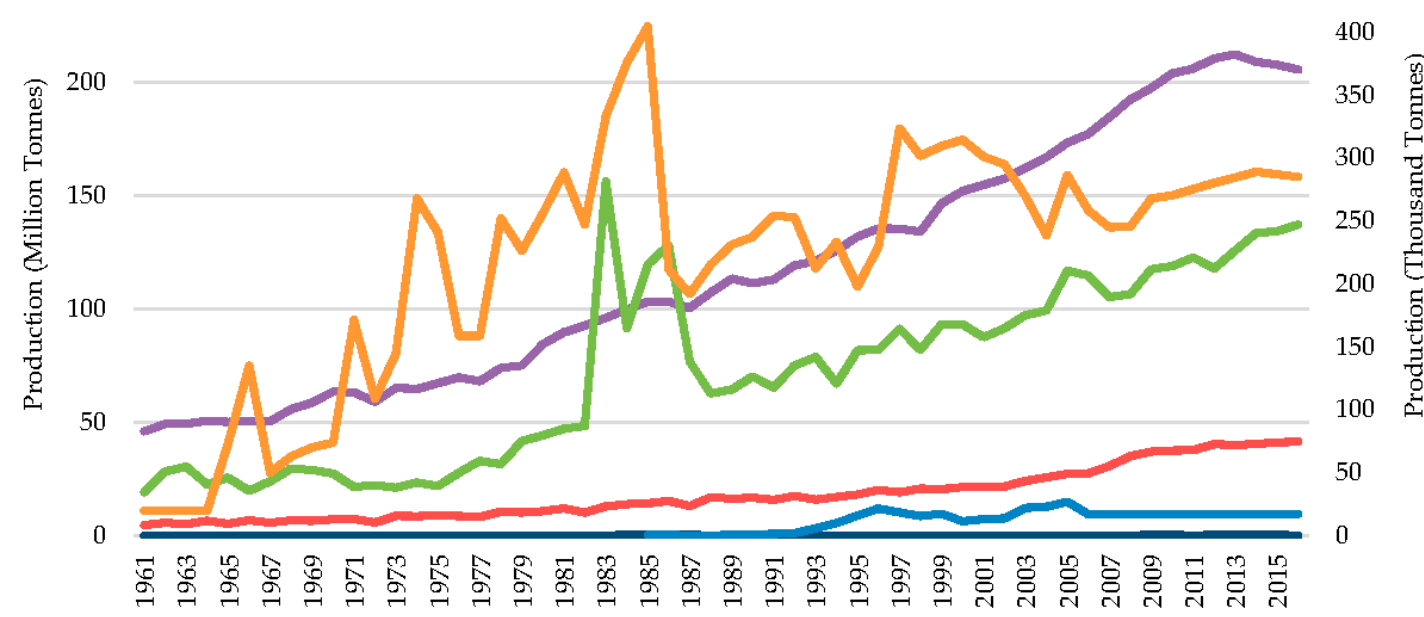

$\longrightarrow$ Maize $\longrightarrow$ Rice $\longrightarrow$ Wheat $\longrightarrow$ Billet $\longrightarrow$ Sorghum

Figure 4. Cont. 


\section{Southern Asia}

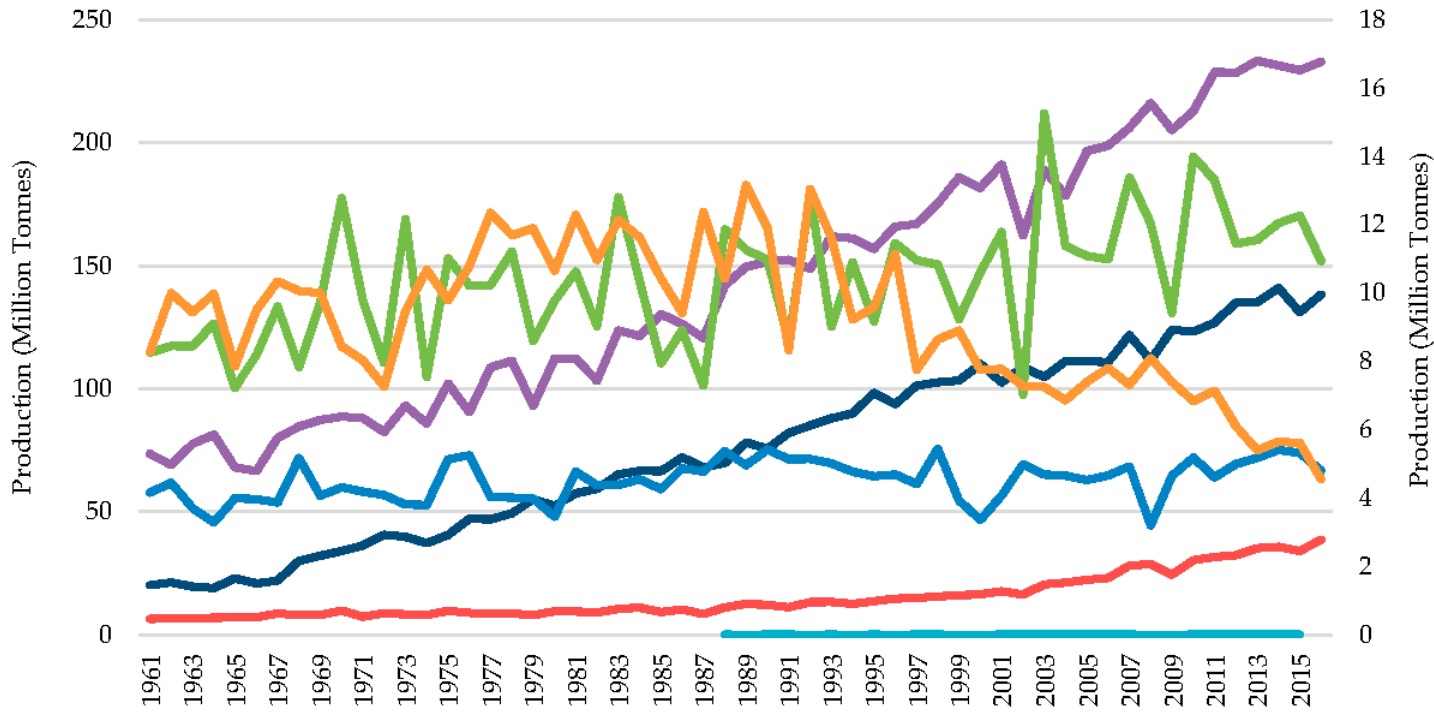

Maize $\longrightarrow$ Rice Wheat $\longrightarrow$ Barley $\longrightarrow$ Millet $=$ Rye $=$ Sorghum

\section{China}

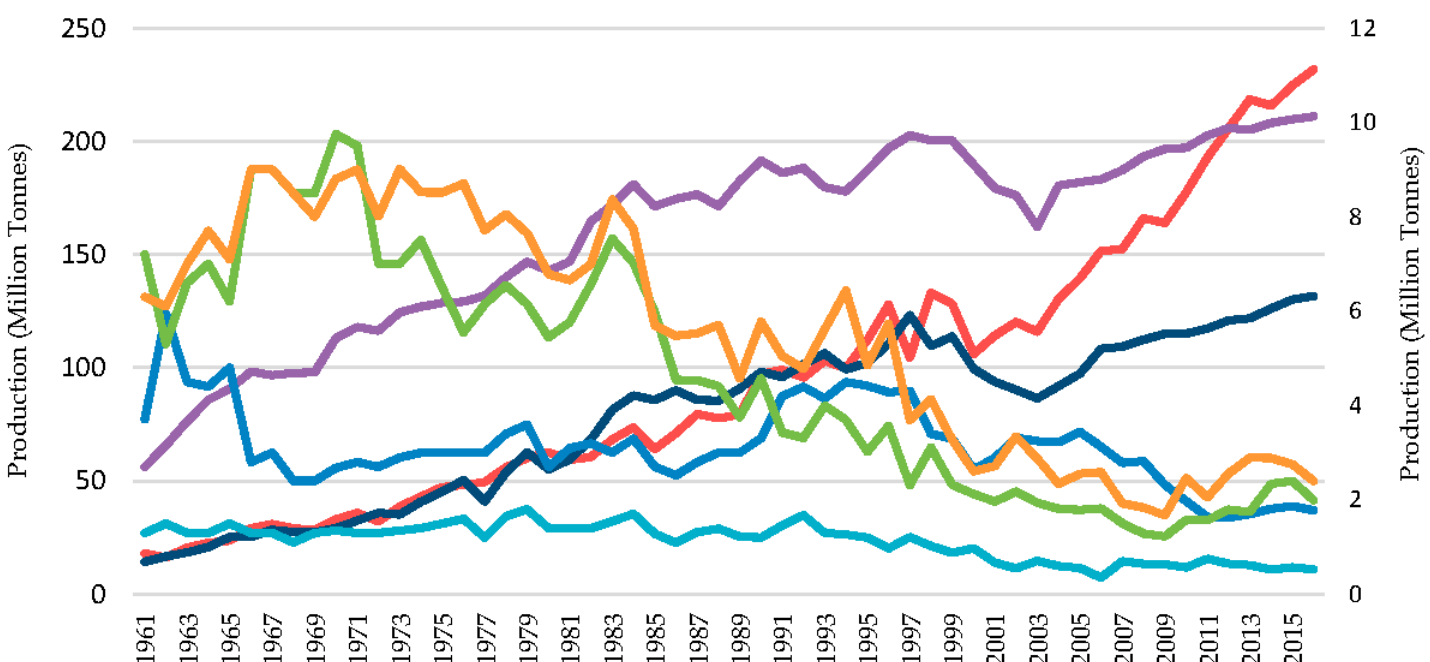

$\longrightarrow$ Maize $\longrightarrow$ Rice Wheat $\longrightarrow$ Billet $=$ Rye $=$ Sorghum

Figure 4. Production of top seven cereal crops in different regions of the world (primary axis represents Maize, Rice and Wheat production in million tons and secondary axis represents Barley, Millet, Rye and Sorghum production in million tons).

From the outlook of this review, the regions that will face adverse effects in terms of soil degradation, water scarcity and climate change are India; China; Western, Middle and Southern Africa; parts of South America; and USA. These countries will face situations that will seriously threaten crop production and food security and may not be able to cope with such adverse effects. Widespread hunger and poverty may result due to the inability of farmers to grow crops because of water shortage which will affect the countries' economy. If proper initiatives are taken at an early 
stage, these adverse effects can be mitigated and. perhaps, a healthy atmosphere could be created where there will be food security so that the coming generation will feel more safe and secure. There is no doubt that a rapid shift in the cropping pattern and eating habits incorporating millets in today's population is vital. This would allow a projected population of 9.1 billion by 2050 to lead a healthy lifestyle, in a world having enough water resources for its subsistence.

Author Contributions: The paper was conceptualized by S.K.V., V.O. and V.R. The methodology, formal analysis and the investigation were carried out by R.S., S.K.V. and J.W. The data curation and analysis were carried out by R.S. and S.K.V. The original draft was prepared by R.S., S.K.V. and J.W. The draft prepared was reviewed and edited by V.R. and V.O. Project administration and the funding for the project were secured by V.R. and V.O.

Funding: The authors would like to thank International Development Research Centre (IDRC), Global Affairs Canada (GAC), and Natural Sciences and Engineering Research Council (NSERC) for funding the study.

Acknowledgments: We would like to acknowledge Darwin Lyew, McGill University and Ashutosh Sharma, IIT Guwahati for their help and support in completing the manuscript.

Conflicts of Interest: The authors do not have any conflict of interests to report.

\section{References}

1. Food and Agriculture Organization of the United Nations. Technical Note: FAO Methodology to Estimate the Prevalence of Undernourishment; FAO: Rome, Italy, 2012.

2. Wheeler, T.; Von Braun, J. Climate change impacts on global food security. Science 2013, 341, 508-513. [CrossRef] [PubMed]

3. Godfray, H.C.J;; Beddington, J.R.; Crute, I.R.; Haddad, L.; Lawrence, D.; Muir, J.F.; Pretty, J.; Robinson, S.; Thomas, S.M.; Toulmin, C. Food security: The challenge of feeding 9 billion people. Science 2010, 327, 812-818. [CrossRef] [PubMed]

4. Kang, Y.; Khan, S.; Ma, X. Climate change impacts on crop yield, crop water productivity and food security-A review. Prog. Nat. Sci. 2009, 19, 1665-1674. [CrossRef]

5. Downing, T.E.; Barrow, E.M.; Brooks, R.J.; Butterfield, R.E.; Carter, T.R.; Harrison, P.A.; Hulme, M.; Olesen, J.E.; Porter, J.R.; Schellberg, J.; et al. Quantification of uncertainty in climate change impact assessment. In Climate Change, Climatic Variability and Agriculture in Europe; Environmental Change Institite: Oxford, UK, 2000; pp. 415-434.

6. Olesen, J.E.; Bindi, M. Consequences of climate change for European agricultural productivity, land use and policy. Eur. J. Agron. 2002, 16, 239-262. [CrossRef]

7. Jain, N.; Arora, P.; Tomer, R.; Mishra, S.V.; Bhatia, A.; Pathak, H.; Chakraborty, D.; Kumar, V.; Dubey, D.; Harit, R.; et al. Greenhouse gases emission from soils under major crops in northwest India. Sci. Total Environ. 2016, 542, 551-561. [CrossRef] [PubMed]

8. Prasad, P.V.; Staggenborg, S.A. Growth and production of sorghum and millets. In Soils, Plant Growth and Crop Production; EOLSS Publishers Co., Ltd.: Oxford, UK, 2009; Volume 2.

9. Awika, J.M. Major cereal grains production and use around the world. In Advances in Cereal Science: Implications to Food Processing and Health Promotion; ACS Publications: Washington, DC, USA, 2011; pp. 1-13.

10. Guigaz, M. Memento Del'agronome; CIRAD-GRETand Ministère desAffairesÉtrangères: Montpellier, France, 2002.

11. International Crops Research Institute for the Semi-Arid Tropics; Food and Agriculture Organization of the United Nations. The World Sorghum and Millet Economies: Facts, Trends, and Outlook; International Crops Research Institute for the Semi-Arid Tropics; Food and Agriculture Organization of the United Nations: Patancheru, India; Rome, Italy, 1996.

12. Passot, S.; Gnacko, F.; Moukouanga, D.; Lucas, M.; Guyomarc'h, S.; Ortega, B.M.; Atkinson, J.A.; Belko, M.N.; Bennett, M.J.; Gantet, P.; et al. Characterization of pearl millet root architecture and anatomy reveals three types of lateral roots. Front. Plant Sci. 2016, 7, 829. [CrossRef] [PubMed]

13. Devi, P.B.; Vijayabharathi, R.; Sathyabama, S.; Malleshi, N.G.; Priyadarisini, V.B. Health benefits of finger millet (Eleusine coracana L.) polyphenols and dietary fiber: A review. J. Food Sci. Technol. 2014, 51, 1021-1040. [CrossRef] [PubMed] 
14. Upadhyaya, H.; Reddy, V.G.; Sastry, D. Regeneration Guidelines Finger Millet; CGIAR System-Wide Genetic Resource Programme: Rome, Italy, 2008.

15. Roshevits, R.Y. Grasses: An Introduction to the Study of Fodder and Cereal Grasses; NTIS: Alexandria, VA, USA, 1980.

16. Baltensperger, D.D. Foxtail and proso millet. In Progress in New Crops; Janick, J., Ed.; ASHS Press: Alexandria, VA, USA, 1996; pp. 182-190.

17. Zarnkow, M.; Mauch, A.; Burberg, F.; Back, W.; Arendt, E.K.; Kreisz, S.; Gastl, M. Proso millet (Panicum miliaceum L.) a sustainable raw material for the malting and brewing process: A review. Brew. Sci. 2009, 62, 119-140.

18. Zarnkow, M.; Keßler, M.; Back, W.; Arendt, E.K.; Gastl, M. Optimisation of the mashing procedure for $100 \%$ malted proso millet (Panicum miliaceum L.) as a raw material for gluten-free beverages and beers. J. Inst. Brew. 2010, 116, 141-150. [CrossRef]

19. Léder, I. Sorghum and millets. Cultiv. Plants Primarily Food Sources 2004, 1, 66-84.

20. Vetriventhan, M.; Upadhyaya, H.; Anandakumar, C.; Senthilvel, S.; Parzies, H.; Bharathi, A.; Varshney, R.; Gowda, C. Assessing genetic diversity, allelic richness and genetic relationship among races in icrisat foxtail millet core collection. Plant Genet. Resour. 2012, 10, 214-223. [CrossRef]

21. Dwivedi, S.U.H.; Senthilvel, S.; Hash, C.T.; Fukunaga, K.; Diao, X.; Santra, D.B.D.; Prasad, M. Genetic and genomic resources. Plant Breed. Rev. 2012, 35, 246-375.

22. Zhang, J.-P.; Liu, T.-S.; Zhang, J.-P.; Liu, T.-S.; Zheng, J.; Zhang, J.-P.; Liu, T.-S.; Zheng, J.; Jin, Z. Cloning and characterization of a putative 12-oxophytodienoic acid reductase cdna induced by osmotic stress in roots of foxtail millet: Full length research paper. DNA Seq. 2007, 18, 138-144. [CrossRef] [PubMed]

23. Yabuno, T. Japanese barnyard millet (Echinochloa Utilis, Poaceae) in Japan. Econ. Bot. 1987, 41, 484-493. [CrossRef]

24. Gomashe, S.S. Barnyard millet: Present Status and Futurethrust Areas. In Millets and Sorghum: Biology and Genetic Improvement; John Wiley \& Sons: Hoboken, NJ, USA, 2016; pp. 184-198.

25. Padulosi, S.; Mal, B.; Bala Ravi, S.; Gowda, J.; Gowda, K.; Shanthakumar, G.; Yenagi, N.; Dutta, M. Food security and climate change: Role of plant genetic resources of minor millets. Indian J. Plant Genet. Resour. 2009, $22,1$.

26. Wallace, J.G.; Upadhyaya, H.D.; Vetriventhan, M.; Buckler, E.S.; Tom Hash, C.; Ramu, P. The genetic makeup of a global barnyard millet germplasm collection. Plant Genome 2015, 8. [CrossRef]

27. House, L.R.; Osmanzai, M.; Gomez, M.I.; Monyo, E.S.; Gupta, S.C. Agronomic Principles. In Sorghum and Millets: Chemistry and Technology; American Association for Cereal Chemist: St. Paul, MN, USA, 1995; pp. 27-67.

28. Arendt, E.; Dal Bello, F. Gluten-Free Cereal Products and Beverages; Academic Press: Cambridge, MA, USA, 2011.

29. Hulse, J.H.; Laing, E.M.; Pearson, O.E. Sorghum and the Millets: Their Composition and Nutritive Value; Academic Press: Cambridge, MA, USA, 1980.

30. Ravi, S.B. Neglected millets that save the poor from starvation. LEISA India 2004, 6, 1-8.

31. Koch, A.; McBratney, A.; Adams, M.; Field, D.; Hill, R.; Crawford, J.; Minasny, B.; Lal, R.; Abbott, L.; O'Donnell, A. Soil security: Solving the global soil crisis. Glob. Policy 2013, 4, 434-441. [CrossRef]

32. McBratney, A.B.; Field, D.J.; Morgan, C.L.; Jarrett, L.E. Soil security: A rationale. In Global Soil Security; Springer: Berlin, Germany, 2017; pp. 3-14.

33. Stott, D.E.; Moebius-Clune, B.N. Soil health: Challenges and opportunities. In Global Soil Security; Springer: Berlin, Germany, 2017; pp. 109-121.

34. U.S. Department of Agriculture, NRCS. Soil Health: Unlock the Secrets of the Soil; U.S. Department of Agriculture, NRCS: Washington, DC, USA, 2012.

35. Lal, R. Soil degradation by erosion. Land Degrad. Dev. 2001, 12, 519-539. [CrossRef]

36. Pimentel, D.; Harvey, C.; Resosudarmo, P.; Sinclair, K.; Kurz, D.; McNair, M.; Crist, S.; Shpritz, L.; Fitton, L.; Saffouri, R. Environmental and economic costs of soil erosion and conservation benefits. Science 1995, 267, 1117-1122. [CrossRef] [PubMed]

37. Troeh, F.R.; Hobbs, J.A.; Donahue, R.L. Soil and water conservation for productivity and environmental protection. Soil Sci. 1981, 132, 189. [CrossRef]

38. Pimentel, D.; Burgess, M. Soil erosion threatens food production. Agriculture 2013, 3, 443-463. [CrossRef] 
39. Patric, J.H. Soil erosion in the eastern forest. J. For. 1976, 74, 671-677.

40. DeVere Burton, L. Agricscience: Fundamentals and Applications; Delmar Cengage Learning: Clifton Park, NY, USA, 2010.

41. Myers, N.; Nath, U.R.; Westlake, M.; Pearson, J. Gaia: An Atlas of Planet Management; Anchor Books: New York, NY, USA, 1984.

42. Eswaran, H.; Lal, R.; Reich, P. Land Degradation: An Overview. Responses to Land Degradation; Oxford Press: New Delhi, India, 2001; pp. 20-35.

43. Reich, P.; Eswaran, H.; Beinroth, F. Global Dimensions of Vulnerability to Wind and Water Erosion, Sustaining the Global Farm. In Proceedings of the 10th International Soil Conservation Organization Meeting, West Lafayette, Indiana, 24-29 May 1999; pp. 838-846.

44. Morgan, R.P.C.; Nearing, M. Handbook of Erosion Modelling; John Wiley \& Sons: Hoboken, NJ, USA, 2016.

45. Morgan, R.; Quinton, J.; Smith, R.; Govers, G.; Poesen, J.; Auerswald, K.; Chisci, G.; Torri, D.; Styczen, M. The European soil erosion model (EUROSEM): A dynamic approach for predicting sediment transport from fields and small catchments. Earth Surf. Process. Landf. 1998, 23, 527-544. [CrossRef]

46. Misra, R.; Rose, C. Application and sensitivity analysis of process-based erosion model guest. Eur. J. Soil Sci. 1996, 47, 593-604. [CrossRef]

47. Jetten, V.G.; de Roo, A.P. Spatial analysis of erosion conservation measures with lisem. In Landscape Erosion and Evolution Modeling; Springer: Berlin, Germany, 2001; pp. 429-445.

48. Renard, K.G. Predicting Soil Erosion by Water: A guide to Conservation Planning with the Revised Universal Soil Loss Equation (RUSLE); United States Department of Agriculture: Washington, DC, USA, 1997.

49. Ewen, J.; Parkin, G.; O'Connell, P.E. Shetran: Distributed river basin flow and transport modeling system. J. Hydrol. Eng. 2000, 5, 250-258. [CrossRef]

50. Ochoa-Cueva, P.; Fries, A.; Montesinos, P.; Rodríguez-Díaz, J.A.; Boll, J. Spatial estimation of soil erosion risk by land-cover change in the andes of southern ecuador. Land Degrad. Dev. 2015, 26, 565-573. [CrossRef]

51. Borrelli, P.; Robinson, D.A.; Fleischer, L.R.; Lugato, E.; Ballabio, C.; Alewell, C.; Meusburger, K.; Modugno, S.; Schütt, B.; Ferro, V. An assessment of the global impact of 21st century land use change on soil erosion. Nat. Commun. 2017, 8, 2013. [CrossRef] [PubMed]

52. Anache, J.A.; Flanagan, D.C.; Srivastava, A.; Wendland, E.C. Land use and climate change impacts on runoff and soil erosion at the hillslope scale in the Brazilian cerrado. Sci. Total Environ. 2018, 622, 140-151. [CrossRef] [PubMed]

53. Costa, C.W.; Lorandi, R.; de Lollo, J.A.; Imani, M.; Dupas, F.A. Surface runoff and accelerated erosion in a peri-urban wellhead area in southeastern Brazil. Environ. Earth Sci. 2018, 77, 160. [CrossRef]

54. Steinhoff-Knopp, B.; Burkhard, B. Soil erosion by water in northern germany: Long-term monitoring results from lower saxony. CATENA 2018, 165, 299-309. [CrossRef]

55. Panagos, P.; Borrelli, P.; Poesen, J.; Ballabio, C.; Lugato, E.; Meusburger, K.; Montanarella, L.; Alewell, C. The new assessment of soil loss by water erosion in Europe. Environ. Sci. Policy 2015, 54, 438-447. [CrossRef]

56. Panagos, P.; Ballabio, C.; Borrelli, P.; Meusburger, K.; Klik, A.; Rousseva, S.; Tadić, M.P.; Michaelides, S.; Hrabalíková, M.; Olsen, P. Rainfall erosivity in Europe. Sci. Total Environ. 2015, 511, 801-814. [CrossRef] [PubMed]

57. Panagos, P.; Meusburger, K.; Ballabio, C.; Borrelli, P.; Alewell, C. Soil erodibility in Europe: A high-resolution dataset based on lucas. Sci. Total Environ. 2014, 479, 189-200. [CrossRef] [PubMed]

58. Panagos, P.; Meusburger, K.; Van Liedekerke, M.; Alewell, C.; Hiederer, R.; Montanarella, L. Assessing soil erosion in Europe based on data collected through a European network. Soil Sci. Plant Nutr. 2014, 60, 15-29. [CrossRef]

59. de Hipt, F.O.; Diekkrüger, B.; Steup, G.; Yira, Y.; Hoffmann, T.; Rode, M. Modeling the impact of climate change on water resources and soil erosion in a tropical catchment in burkina faso, west Africa. CATENA 2018, 163, 63-77. [CrossRef]

60. Diwediga, B.; Le, Q.B.; Agodzo, S.K.; Tamene, L.D.; Wala, K. Modelling soil erosion response to sustainable landscape management scenarios in the mo river basin (Togo, West Africa). Sci. Total Environ. 2018, 625, 1309-1320. [CrossRef]

61. Fenta, A.A.; Yasuda, H.; Shimizu, K.; Haregeweyn, N.; Kawai, T.; Sultan, D.; Ebabu, K.; Belay, A.S. Spatial distribution and temporal trends of rainfall and erosivity in the eastern africa region. Hydrol. Process. 2017, 31, 4555-4567. [CrossRef] 
62. Panagos, P.; Borrelli, P.; Meusburger, K.; Yu, B.; Klik, A.; Lim, K.J.; Yang, J.E.; Ni, J.; Miao, C.; Chattopadhyay, N. Global rainfall erosivity assessment based on high-temporal resolution rainfall records. Sci. Rep. 2017, 7, 4175. [CrossRef] [PubMed]

63. Wang, Y.; Cheng, C.; Xie, Y.; Liu, B.; Yin, S.; Liu, Y.; Hao, Y. Increasing trends in rainfall-runoff erosivity in the source region of the three rivers, 1961-2012. Sci. Total Environ. 2017, 592, 639-648. [CrossRef] [PubMed]

64. Giang, P.Q.; Giang, L.T.; Toshiki, K. Spatial and temporal responses of soil erosion to climate change impacts in a transnational watershed in southeast Asia. Climate 2017, 5, 22. [CrossRef]

65. Jat, M.L.; Stirling, C.M.; Jat, H.S.; Tetarwal, J.P.; Jat, R.K.; Singh, R.; Lopez-Ridaura, S.; Shirsath, P.B. Soil processes and wheat cropping under emerging climate change scenarios in south asia. Adv. Agron. 2017. [CrossRef]

66. Kisan, M.V.; Khanindra, P.; Narayan, T.K.; Kumar, T.S. Remote sensing and gis based assessment of soil erosion and soil loss risk around hill top surface mines situated in saranda forest, jharkhand. J. Water Clim. Chang. 2016, 7, 68-82. [CrossRef]

67. Mondal, A.; Khare, D.; Kundu, S.; Meena, P.K.; Mishra, P.; Shukla, R. Impact of climate change on future soil erosion in different slope, land use, and soil-type conditions in a part of the narmada river basin, India. J. Hydrol. Eng. 2014, 20, C5014003. [CrossRef]

68. Thomas, J.; Joseph, S.; Thrivikramji, K. Assessment of soil erosion in a tropical mountain river basin of the Southern Western Ghats, India using rusle and GIS. Geosci. Front. 2017. [CrossRef]

69. Bao, Y.; He, X.; Wei, J.; Tang, Q.; Guo, F. Soil erosion under different land uses in the riparian zone of the three-gorge reservoir, China. IAHS Publ. 2012, 356, 198-201.

70. Su, Z.; Xiong, D.; Dong, Y.; Yang, D.; Zhang, S.; Zhang, B.; Zheng, X.; Zhang, J.; Shi, L. Influence of bare soil and cultivated land use types upstream of a bank gully on soil erosion rates and energy consumption for different gully erosion zones in the dry-hot valley region, Southwest China. Nat. Hazards 2015, 79, 183-202. [CrossRef]

71. Jin, X.; Cheng, G.; Xu, C.; Fan, J.; Ma, Z. Estimation of the spatial distribution of soil erosion in the hilly area of Sichuan, China. IAHS-AISH Publ. 2012, 356, 228-234.

72. Vörösmarty, C.J.; Green, P.; Salisbury, J.; Lammers, R.B. Global water resources: Vulnerability from climate change and population growth. Science 2000, 289, 284-288. [CrossRef] [PubMed]

73. Islam, M.S.; Oki, T.; Kanae, S.; Hanasaki, N.; Agata, Y.; Yoshimura, K. A grid-based assessment of global water scarcity including virtual water trading. Water Resour. Manag. 2007, 21, 19-33. [CrossRef]

74. Alcamo, J.; Flörke, M.; Märker, M. Future long-term changes in global water resources driven by socio-economic and climatic changes. Hydrol. Sci. J. 2007, 52, 247-275. [CrossRef]

75. Arnell, N.W. Climate change and global water resources: Sres emissions and socio-economic scenarios. Glob. Environ. Chang. 2004, 14, 31-52. [CrossRef]

76. Gerten, D.; Heinke, J.; Hoff, H.; Biemans, H.; Fader, M.; Waha, K. Global water availability and requirements for future food production. J. Hydrometeorol. 2011, 12, 885-899. [CrossRef]

77. Falkenmark, M.; Rockström, J.; Karlberg, L. Present and future water requirements for feeding humanity. Food Secur. 2009, 1, 59-69. [CrossRef]

78. Rost, S.; Gerten, D.; Bondeau, A.; Lucht, W.; Rohwer, J.; Schaphoff, S. Agricultural green and blue water consumption and its influence on the global water system. Water Resour. Res. 2008, 44. [CrossRef]

79. Liu, J.; Zehnder, A.J.; Yang, H. Global consumptive water use for crop production: The importance of green water and virtual water. Water Resour. Res. 2009, 45. [CrossRef]

80. Rockström, J.; Falkenmark, M.; Karlberg, L.; Hoff, H.; Rost, S.; Gerten, D. Future water availability for global food production: The potential of green water for increasing resilience to global change. Water Resour. Res. 2009, 45. [CrossRef]

81. Food and Agriculture Organization. World Agriculture: Towards 2015/2030-An FAO Perspective; Earthscan: London, UK, 2003; 432p.

82. Jaeger, W.K.; Amos, A.; Bigelow, D.P.; Chang, H.; Conklin, D.R.; Haggerty, R.; Langpap, C.; Moore, K.; Mote, P.W.; Nolin, A.W. Finding water scarcity amid abundance using human-natural system models. Proc. Natl. Acad. Sci. USA 2017, 114, 11884-11889. [CrossRef] [PubMed]

83. MacDonald, G.M. Water, climate change, and sustainability in the southwest. Proc. Natl. Acad. Sci. USA 2010, 107, 21256-21262. [CrossRef] [PubMed] 
84. Porkka, M.; Gerten, D.; Schaphoff, S.; Siebert, S.; Kummu, M. Causes and trends of water scarcity in food production. Environ. Res. Lett. 2016, 11, 015001. [CrossRef]

85. Devia, G.K.; Ganasri, B.; Dwarakish, G. A review on hydrological models. Aquat. Procedia 2015, 4, $1001-1007$. [CrossRef]

86. Sorooshian, S.; Hsu, K.-L.; Coppola, E.; Tomassetti, B.; Verdecchia, M.; Visconti, G. Hydrological Modelling and the Water Cycle: Coupling the Atmospheric and Hydrological Models; Springer Science \& Business Media: Berlin, Germany, 2008; Volume 63.

87. Getirana, A. Extreme water deficit in Brazil detected from space. J. Hydrometeorol. 2016, 17, 591-599. [CrossRef]

88. Hirata, R.; Conicelli, B.P. Groundwater resources in Brazil: A review of possible impacts caused by climate change. Anais da Academia Brasileira de Ciências 2012, 84, 297-312. [CrossRef] [PubMed]

89. Murtinho, F.; Tague, C.; de Bievre, B.; Eakin, H.; Lopez-Carr, D. Water scarcity in the andes: A comparison of local perceptions and observed climate, land use and socioeconomic changes. Hum. Ecol. 2013, 41, 667-681. [CrossRef]

90. Seiler, C.; Hutjes, R.W.; Kabat, P. Likely ranges of climate change in Bolivia. J. Appl. Meteorol. Climatol. 2013, 52, 1303-1317. [CrossRef]

91. Feng, S.; Fu, Q. Expansion of global drylands under a warming climate. Atmos. Chem. Phys 2013, 13, 14637-14665. [CrossRef]

92. Montaña, E.; Diaz, H.P.; Hurlbert, M. Development, local livelihoods, and vulnerabilities to global environmental change in the south american dry andes. Reg. Environ. Chang. 2016, 16, 2215-2228. [CrossRef]

93. Terrado, M.; Acuña, V.; Ennaanay, D.; Tallis, H.; Sabater, S. Impact of climate extremes on hydrological ecosystem services in a heavily humanized mediterranean basin. Ecol. Indic. 2014, 37, 199-209. [CrossRef]

94. Marquès, M.; Bangash, R.F.; Kumar, V.; Sharp, R.; Schuhmacher, M. The impact of climate change on water provision under a low flow regime: A case study of the ecosystems services in the francoli river basin. J. Hazard. Mater. 2013, 263, 224-232. [CrossRef] [PubMed]

95. Lutter, S.; Pfister, S.; Giljum, S.; Wieland, H.; Mutel, C. Spatially explicit assessment of water embodied in European trade: A product-level multi-regional input-output analysis. Glob. Environ. Chang. 2016, 38, 171-182. [CrossRef]

96. Liuzzo, L.; Noto, L.V.; Arnone, E.; Caracciolo, D.; La Loggia, G. Modifications in water resources availability under climate changes: A case study in a sicilian basin. Water Resour. Manag. 2015, 29, 1117-1135. [CrossRef]

97. Maestre-Valero, J.F.; Martínez-Granados, D.; Martínez-Alvarez, V.; Calatrava, J. Socio-economic impact of evaporation losses from reservoirs under past, current and future water availability scenarios in the semi-arid segura basin. Water Resour. Manag. 2013, 27, 1411-1426. [CrossRef]

98. Koop, S.H.A.; van Leeuwen, C.J. The challenges of water, waste and climate change in cities. Environ. Dev. Sustain. 2017, 19, 385-418. [CrossRef]

99. Aich, V.; Liersch, S.; Vetter, T.; Huang, S.; Tecklenburg, J.; Hoffmann, P.; Koch, H.; Fournet, S.; Krysanova, V.; Müller, E. Comparing impacts of climate change on streamflow in four large african river basins. Hydrol. Earth Syst. Sci. 2014, 18, 1305. [CrossRef]

100. Brinkmann, K.; Schumacher, J.; Dittrich, A.; Kadaore, I.; Buerkert, A. Analysis of landscape transformation processes in and around four west african cities over the last 50 years. Landsc. Urban Plan. 2012, 105, 94-105. [CrossRef]

101. Schmitz, C.; Lotze-Campen, H.; Gerten, D.; Dietrich, J.P.; Bodirsky, B.; Biewald, A.; Popp, A. Blue water scarcity and the economic impacts of future agricultural trade and demand. Water Resour. Res. 2013, 49, 3601-3617. [CrossRef]

102. Jemmali, H. Mapping water poverty in africa using the improved multidimensional index of water poverty. Int. J. Water Resour. Dev. 2017, 33, 649-666. [CrossRef]

103. Prasch, M.; Mauser, W.; Weber, M. Quantifying present and future glacier melt-water contribution to runoff in a central himalayan river basin. Cryosphere 2013, 7, 889. [CrossRef]

104. Máñez, K.S.; Husain, S.; Ferse, S.C.; Costa, M.M. Water scarcity in the spermonde archipelago, sulawesi, indonesia: Past, present and future. Environ. Sci. Policy 2012, 23, 74-84. [CrossRef]

105. Riadi, L. Water sustainability: Emerging trends for water quality management. KnE Life Sci. 2017, 3, 118-130. [CrossRef] 
106. Mekonnen, M.M.; Hoekstra, A.Y. Four billion people facing severe water scarcity. Sci. Adv. 2016, 2, e1500323. [CrossRef] [PubMed]

107. Wang, K.; Sun, D.-W.; Pu, H.; Wei, Q. Principles and applications of spectroscopic techniques for evaluating food protein conformational changes: A review. Trends Food Sci. Technol. 2017, 67, 207-219. [CrossRef]

108. Ramkar, P.; Yadav, S. Spatiotemporal drought assessment of a semi-arid part of middle tapi river basin, India. Int. J. Disaster Risk Reduct. 2018, 28, 414-426. [CrossRef]

109. Hejazi, M.; Edmonds, J.; Clarke, L.; Kyle, P.; Davies, E.; Chaturvedi, V.; Wise, M.; Patel, P.; Eom, J.; Calvin, K. Long-term global water projections using six socioeconomic scenarios in an integrated assessment modeling framework. Technol. Forecast. Soc. Chang. 2014, 81, 205-226. [CrossRef]

110. Ahammed, S.J.; Chung, E.-S.; Shahid, S. Parametric assessment of pre-monsoon agricultural water scarcity in bangladesh. Sustainability 2018, 10, 819. [CrossRef]

111. Quinteiro, P.; Rafael, S.; Villanueva-Rey, P.; Ridoutt, B.; Lopes, M.; Arroja, L.; Dias, A.C. A characterisation model to address the environmental impact of green water flows for water scarcity footprints. Sci. Total Environ. 2018, 626, 1210-1218. [CrossRef] [PubMed]

112. Feng, K.; Siu, Y.L.; Guan, D.; Hubacek, K. Assessing regional virtual water flows and water footprints in the yellow river basin, China: A consumption based approach. Appl. Geogr. 2012, 32, 691-701. [CrossRef]

113. Feng, K.; Hubacek, K.; Pfister, S.; Yu, Y.; Sun, L. Virtual scarce water in China. Environ. Sci. Technol. 2014, 48, 7704-7713. [CrossRef] [PubMed]

114. Bruinsma, J. World Agriculture: Towards 2015/2030: An FAO Study; Routledge: Abingdon, UK, 2017.

115. Lesk, C.; Rowhani, P.; Ramankutty, N. Influence of extreme weather disasters on global crop production. Nature 2016, 529, 84-87. [CrossRef] [PubMed]

116. Lipper, L.; Thornton, P.; Campbell, B.M.; Baedeker, T.; Braimoh, A.; Bwalya, M.; Caron, P.; Cattaneo, A.; Garrity, D.; Henry, K. Climate-smart agriculture for food security. Nat. Clim. Chang. 2014, 4, 1068-1072. [CrossRef]

117. de Vrese, P.; Stacke, T.; Hagemann, S. Exploring the biogeophysical limits of global food production under different climate change scenarios. Earth Syst. Dyn. 2018, 9, 393-412. [CrossRef]

118. Levis, S.; Badger, A.; Drewniak, B.; Nevison, C.; Ren, X. Clmcrop yields and water requirements: Avoided impacts by choosing rcp 4.5 over 8.5. Clim. Chang. 2018, 146, 501-515. [CrossRef]

119. Wang, Q.; Wu, J.; Lei, T.; He, B.; Wu, Z.; Liu, M.; Mo, X.; Geng, G.; Li, X.; Zhou, H. Temporal-spatial characteristics of severe drought events and their impact on agriculture on a global scale. Quat. Int. 2014, 349, 10-21. [CrossRef]

120. Geng, G.; Wu, J.; Wang, Q.; Lei, T.; He, B.; Li, X.; Mo, X.; Luo, H.; Zhou, H.; Liu, D. Agricultural drought hazard analysis during 1980-2008: A global perspective. Int. J. Clim. 2016, 36, 389-399. [CrossRef]

121. Thaler, S.; Eitzinger, J.; Trnka, M.; Dubrovsky, M. Impacts of climate change and alternative adaptation options on winter wheat yield and water productivity in a dry climate in central Europe. J. Agric. Sci. 2012, 150, 537-555. [CrossRef]

122. Eitzinger, J.; Trnka, M.; Semerádová, D.; Thaler, S.; Svobodová, E.; Hlavinka, P.; Šiška, B.; Takáč, J.; Malatinská, L.; Nováková, M. Regional climate change impacts on agricultural crop production in central and eastern Europe-hotspots, regional differences and common trends. J. Agric. Sci. 2013, 151, 787-812. [CrossRef]

123. Knox, J.; Daccache, A.; Hess, T.; Haro, D. Meta-analysis of climate impacts and uncertainty on crop yields in Europe. Environ. Res. Lett. 2016, 11, 113004. [CrossRef]

124. Bakker, A.M.; Bessembinder, J.J.; de Wit, A.J.; van den Hurk, B.J.; Hoek, S.B. Exploring the efficiency of bias corrections of regional climate model output for the assessment of future crop yields in Europe. Reg. Environ. Chang. 2014, 14, 865-877. [CrossRef]

125. Parkes, B.; Defrance, D.; Sultan, B.; Ciais, P.; Wang, X. Projected changes in crop yield mean and variability over west africa in a world $1.5 \mathrm{k}$ warmer than the pre-industrial era. Earth Syst. Dyn. 2018, 9, 119-134. [CrossRef]

126. Sultan, B.; Guan, K.; Kouressy, M.; Biasutti, M.; Piani, C.; Hammer, G.; McLean, G.; Lobell, D.B. Robust features of future climate change impacts on sorghum yields in west africa. Environ. Res. Lett. 2014, 9, 104006. [CrossRef]

127. Knox, J.; Hess, T.; Daccache, A.; Wheeler, T. Climate change impacts on crop productivity in Africa and South Asia. Environ. Res. Lett. 2012, 7, 034032. [CrossRef] 
128. Hoffman, A.L.; Kemanian, A.R.; Forest, C.E. Analysis of climate signals in the crop yield record of sub-saharan Africa. Glob. Chang. Biol. 2018, 24, 143-157. [CrossRef] [PubMed]

129. Yuliawan, T.; Handoko, I. The effect of temperature rise to rice crop yield in indonesia uses shierary rice model with geographical information system (GIS) feature. Procedia Environ. Sci. 2016, 33, 214-220. [CrossRef]

130. Kurniasih, E. Use of Drought Index and Crop Modelling for Drought Impacts Analysis on Maize (Zea Mays L.) Yield Loss in Bandung District; IOP Conference Series: Earth and Environmental Science; IOP Publishing: Bristol, UK, 2017; p. 012036.

131. Prabnakorn, S.; Maskey, S.; Suryadi, F.; de Fraiture, C. Rice yield in response to climate trends and drought index in the mun river basin, thailand. Sci. Total Environ. 2018, 621, 108-119. [CrossRef] [PubMed]

132. Chen, Y.; Lu, C. A comparative analysis on food security in Bangladesh, India and Myanmar. Sustainability 2018, 10, 405. [CrossRef]

133. Arshad, M.; Amjath-Babu, T.; Aravindakshan, S.; Krupnik, T.J.; Toussaint, V.; Kächele, H.; Müller, K. Climatic variability and thermal stress in pakistan's rice and wheat systems: A stochastic frontier and quantile regression analysis of economic efficiency. Ecol. Indic. 2018, 89, 496-506. [CrossRef]

134. Dar, M.U.D.; Aggarwal, R.; Kaur, S. Effect of climate change scenarios on yield and water balance components in rice-wheat cropping system in Central Punjab, India. J. Agrometeorol. 2017, 19, 226-229.

135. Zhang, T.; Huang, Y. Impacts of climate change and inter-annual variability on cereal crops in China from 1980 to 2008. J. Sci. Food Agric. 2012, 92, 1643-1652. [CrossRef] [PubMed]

136. Ye, L.; Xiong, W.; Li, Z.; Yang, P.; Wu, W.; Yang, G.; Fu, Y.; Zou, J.; Chen, Z.; Van Ranst, E.; et al. Climate change impact on China food security in 2050. Agron. Sustain. Dev. 2013, 33, 363-374. [CrossRef]

137. Tao, F; Zhang, Z. Climate change, wheat productivity and water use in the north China plain: A new super-ensemble-based probabilistic projection. Agric. For. Meteorol. 2013, 170, 146-165. [CrossRef]

138. Lv, Z.; Liu, X.; Cao, W.; Zhu, Y. Climate change impacts on regional winter wheat production in main wheat production regions of China. Agric. For. Meteorol. 2013, 171, 234-248. [CrossRef]

139. Wang, J.; Vanga, S.K.; Saxena, R.; Orsat, V.; Raghavan, V. Effect of climate change on the yield of cereal crops: A review. Climate 2018, 6, 41. [CrossRef]

140. Khapre, A.P. Studies on Development of Value Added Products from Finger Millet (Eleusine Coracana) and Foxtail Millet (Setaria Italica) for Nutritional Security; Vasantrao Naik Marathwada Krishi Vidyapeeth: Parbhani, India, 2017.

141. Michaelraj, P.; Shanmugam, A. A study on milletsbased cultivation and consumption in India. Int. J. Mark. Financ. Serv. Manag. Res. 2013, 2, 49-58.

142. Malathi, B.; Appaji, C.; Reddy, G.R.; Dattatri, K.; Sudhakar, N. Growth pattern of millets in India. Indian J. Agric. Res. 2016, 50, 382-386. [CrossRef] 